\title{
Archeoseismic study of damage in Roman and Medieval structures in the center of Cologne, Germany
}

\author{
Klaus-G. Hinzen • Stephan Schreiber • Claus Fleischer • \\ Sharon K. Reamer • Isabel Wiosna
}

Received: 28 March 2012 / Accepted: 30 July 2012 /Published online: 29 August 2012

(C) The Author(s) 2012. This article is published with open access at Springerlink.com

\begin{abstract}
The causes of damage observed in archeological records or preserved monuments are often difficult to be determined unequivocally, particularly when the possibility of secondary earthquake damage exists. Such secondary damage has been previously proposed for the Roman Praetorium, the governor's palace in the center of Cologne. Ongoing excavations since 2007 revealed additional damage. The existing ground that has been uncovered and documented extends the affected area to $175 \times 180 \mathrm{~m}$. We present a comprehensive virtual model of the excavation area based on 200 3D laserscans together with a systematic analysis of the damage patterns and an improved model of the terrain during Roman/Medieval times including geotechnical parameters of the subsurface. Five locations with different damage patterns, including a Roman sewer, the octagonal central part of the Praetorium, a section with strongly inclined massive walls, a $13 \mathrm{~m}$ deep deformed well, a collapsed hypocaust, and damages in the Medieval mikveh are analyzed in detail. We use site-specific synthetic strong ground motion seismograms to test the possibility of
\end{abstract}

K.-G. Hinzen $(\bowtie) \cdot$ S. Schreiber $\cdot$ C. Fleischer

S. K. Reamer - I. Wiosna

Earthquake Geology and Archaeoseismology Group,

Institute for Geology and Mineralogy,

University of Cologne,

Vinzenz-Pallotti-Str. 26,

51429 Bergisch Gladbach, Germany

e-mail: hinzen@uni-koeln.de

URL: www.seismo.uni-koeln.de earthquake-induced ground failures as a cause for the observed damage. This subsurface model is also used to test the possibility of hydraulically-induced damages by seepage and erosion of fine-grained material from stray sand. Heavy rainstorms can induce a direct stream of surface water through the fine sand layers to the ground water table. Simulated ground motion for assumed worst-case earthquake scenarios do not provoke slope instability at the level necessary to explain the structural damages.

Keywords Archeoseismology Earthquake .

Laserscanning · Slope stability · Seepage $\cdot$ Lower Rhine Embayment $\cdot$ Cologne

\section{Introduction}

An unequivocal cause of damage observed in archeological records or preserved monuments is often difficult to determine. Various natural causes may result in similar damage patterns (Galadini et al. 2006), and anthropogenic action can also produce similarlooking damage or deformations (Nikonov 1988). If targets of archeoseismological studies are being excavated in an ongoing project, it follows that major anthropogenic actions have not occurred since coverage of the targets. Unless located directly on a fault zone (Ellenblum et al. 1998; Meghraoui et al. 2003; Marco 2008), earthquake ground motions affecting a specific location after the burial of the objects are not 
generally responsible for significant altering of such buried targets. Preserved monuments, however, which have been visible and accessible at the surface since their construction could have suffered subsequent damage or deformation. In addition, anthropogenic alterations could have occurred throughout the history of the object including restorations, construction of more recent buildings, and architectural modifications to permit a different use (Galadini et al. 2006). Prominent examples of such monuments are the Parthenon in Athens and the Colosseum in Rome. Compared to such large architectonical structures for practical use, grave houses, large sarcophaguses, and other structures of necropolises are less likely to be used for purposes other than their original intent. However, numerous examples show that such structures were often the target of looters, sometimes immediately subsequent to construction, sometimes late in the objects' history (Hinzen et al. 2010). In cases where both natural and man-made causes of damage or deformation are possible (Guidoboni 2002; Ambraseys 2005; Galadini et al. 2006), both kinds of sources should be parameterized and modeled, thereby necessitating construction of an appropriate parameter space to test the plausibility of competing hypotheses.

The Cologne Praetorium, the palace of the Roman governor of the province of germania inferior, was initially excavated and partially preserved in the 1950s. All modern buildings in this area had been destroyed during WWII aerial bombing and Roman foundations were exposed during the construction of a new city hall. These foundations and remaining parts of the standing walls show severe structural damage, especially concentrated at the central octagonal part of the former building. The remains of the Praetorium include walls from four building phases (I to IV) between the first and the fourth century CE; however, only the best-preserved walls dating from phases III and IV show significant damage.

The early excavators (Precht 1973) assumed slow static settlements due to a weak subsurface and inadequate building technique as the main cause of the breakdown of wall sections. Hinzen and Schütte (2003) argued for a more sudden event that affected the building ground and subsequently the integrity of the structure. They found arguments for secondary earthquake damage, however also pointed out the need to test for possible hydrologic causes.
Since 2007, extensive excavations immediately south of the Praetorium and of a newly excavated section of a Roman sewer north of the Praetorium provided an opportunity to collect data from a hitherto inaccessible section of the subsurface. The current excavation area (Schütte and Gechter 2011) includes the Medieval Jewish quarter of Cologne, which hosted one of the earliest Jewish communities in Europe.

In this study, we (1) present a comprehensive virtual model of the archeological inventory in a $175 \times$ $180 \mathrm{~m}$ area that includes the Cologne Praetorium based on detailed laserscan measurements, (2) quantify the damage to selected subsections, (3) use an improved seismotectonic model to calculate site specific synthetic seismograms for deterministic earthquake scenarios, (4) test the static and dynamic stability of the subsurface, (5) simulate seepage during heavy rain storm cycles to test for possible internal suffusion and erosion processes, and (6) review aerial surveillance photos taken after WWII bomb attacks.

\section{Location}

\subsection{Tectonic and seismicity}

The study area in the city center of Cologne is located in the eastern part of the Lower Rhine Embayment (LRE; Fig. 1). The LRE is part of the Rhine-Rhone Rift system. The current period of tectonic movements in the LRE is closely related to the late Tertiary graben structures and started with small but widely distributed displacements along faults in the late Miocene. During the Pliocene, faulting was more intense and cumulated in late Pliocene and early Pleistocene. Considerable synsedimentary and intersedimentary crustal displacements occurred in the Quaternary when the Older and Younger Lower Terraces of the Rhine and Meuse (Maas) River were accumulated (Ahorner 1962; Hinzen and Reamer 2007). The main faults with a cumulative length of more than $400 \mathrm{~km}$ are generally directed in a NW-SE strike. The LRE shows moderate seismicity in present and historic times (Fig. 1). Instrumentally observed earthquakes in the LRE include the $1992 \mathrm{M}_{\mathrm{W}} 5.4$ Roermond earthquake (Camelbeeck et al. 1994). The strongest historically documented earthquake in the area is the 1692 Vervier earthquake west of the LRE with an estimated magni-

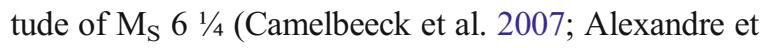




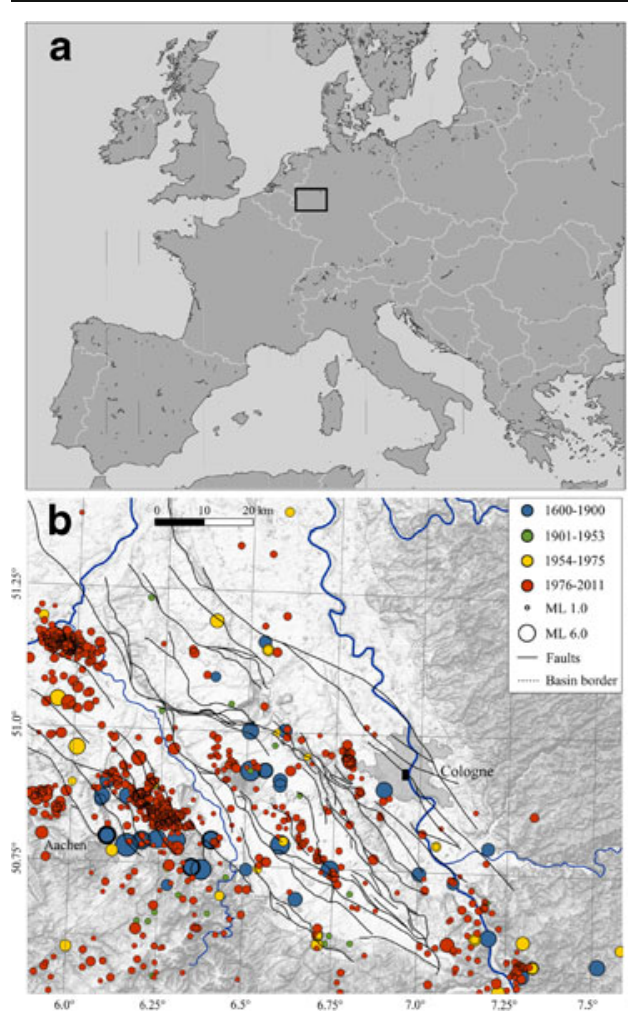

Fig. 1 a Location of the map shown in $\mathbf{b}$ within Europe. b Seismicity and active faults (black lines) in the Lower Rhine Embayment. Historical, early instrumental, and recent earthquake epicenters are color coded as shown in the legend. The

al. 2008). A Gutenberg-Richter seismicity model of the area predicts an occurrence of $8.65 \times 10^{-4}$ for a $\mathrm{M}_{\mathrm{W}} 6.0$ earthquake (Reamer and Hinzen 2004). Palaeoseismic studies and the extension of active fault segments indicate maximum magnitudes of $\mathrm{M}_{\mathrm{W}}$ 6.8-7.0 (Camelbeeck and Meghraouhi 1998; Vanneste and Verbeeck 2001; Vanneste et al. 2001; Ahorner 2001; Schmedes et al. 2005; Hinzen and Reamer 2007). The main earthquake activity in recent and historic times is found in the western part of the LRE, while Weber and Hinzen (2006) showed evidence for recent seismic activity east of the Rhine River in the form of several microearthquakes. It should be noted that Vanneste et al. (2012) do not include these faults reported in Fig. $1 \mathrm{~b}$ among those of their new active fault model.

\subsection{History and archeological setting}

The northward extension of the Roman Empire in the last century BCE and the first century CE produced location of the study area in Cologne next to the Rhine River is indicated by the black rectangle. c Overview of the study area; the major contours of the Roman and Medieval constructions are shown in red

enormous building activity, and some well-preserved buildings from this period exist in central Europe. During the Roman period, building activity boomed. Agrippina, the wife of the Emperor Claudius, made her birth town in $50 \mathrm{CE}$ a colony with the name Colonia Claudia Ara Agrippinensium (CCAA), and the inhabitants became Roman citizens. The name 'Claudia' goes back to the family of the ruling emperors, the Claudians; "Ara" refers to Ara Ubiorum, the name of the main altar of the Germanic province, the germania inferior (La Baume 1980). The settlement was located on a plateau of $1 \mathrm{~km}^{2}$ of the Lower Terrace, ca. 14-16 m above the Rhine River and safely above the level of flooding (Gechter and Schütte 2000). To the east, an arm of the Rhine River bordered this settlement. The city walls of the Oppidum Ubiorum were laid out in a rectangular pattern similar to Italian Roman town foundations, while the city walls of the second half of the first century CE followed the irregular pattern of the terrace edges 
(Doppelfeld 1956). At the riverbank, the city wall (Fig. 1) did not follow the terrace edge but was placed right at the waterline. The investigated structures are located on this terrace and in the area of the slope towards a former side arm of the Rhine River.

A summary of the history of the archeology of the area is given by Schütte and Gechter (2011). Already in the thirteenth century people building a new house opposite the city hall were aware that this new structure was founded on Roman walls. Weinsberg (Höhlbaum 1887) described in 1570 Jewish and Roman foundation walls on the town hall square. Gelenius (1645) published an inscription that gave clear reference to the Cologne Praetorium. During construction works on the town hall between 1861 and 1865 , subsurface walls were recognized as those of the Roman Praetorium and Schultze et al. (1885) closely examined these walls, but they interpreted them as Franconian.

Due to the more than $95 \%$ damaged part of downtown Cologne, intense construction work was initiated after WWII. During the excavations for a new administration building at the location of the destroyed "Spanischer Bau," monumental walls were discovered, and for which the archeologist Doppelfeld (1956) was urged to complete the excavations of in a mere 6 months. Luckily, the City Council decided to preserve the northern part of the new archeological findings of the Roman Praetorium underneath a selfsupporting arced reinforced concrete ceiling. Additional excavations mainly south of the Praetorium were made subsequently by Precht (1973) who also gave a detailed description and interpretation of the building sequences. Recently, an open plan for an extension of the existing museum underneath the town hall was revived. In 2007 , further excavations started and are ongoing at the time of the writing of this paper. The new excavation area (Fig. 1) includes the Medieval Jewish quarter of Cologne with a synagogue, a mikveh, a hospital and numerous residential buildings.

\section{Studied structures}

Figure 1c shows a plan of the main structures of the study area, which are from north to south: the northern main sewer, the Praetorium including the octagonal shaped central tower, the so-called Porticus with the Jewish hospital adjoining a massive Roman wall, a
Roman well, the Medieval synagogue complex with a large cesspit, a buried collapsed hypocaust, a deformed structure underneath the women's synagogue; the mikveh with damaged walls in a former entrance, and the residential area with a deformed staircase of Late Medieval. While the western part of the northern sewer and northern two thirds of the Praetorium were already preserved and open to the public, all other structures became accessible during the recent and ongoing excavations for the construction of the Archaeological Zone Cologne. The excavation is unique: it is located right in the center of a megacity and covers 2,000 years of building history. It is in parts more than $10 \mathrm{~m}$ deep, includes effects of several pogroms (i.e., 1096, 1349) and wars, especially heavy damage during WWII, and thus constitutes a challenge for archeological and archeoseismological work.

\subsection{D laser scan model}

We used the laser scanning technique to create a comprehensive virtual model (CVM) of the remains of the whole excavation complex (Schreiber et al. 2009, 2012; Schreiber and Hinzen 2011). In full resolution, the CVM contains 2.3 billion georeferenced 3D points. Special challenges included the repeated scanning of the $8.3 \mathrm{~m}$ deep cesspit during its excavation (Schreiber et al. 2012) and the $13 \mathrm{~m}$ deep Roman well (Fleischer et al. 2010). The CVM enhances visualization and quantification of the damage found in the study area, which were previously described (i.e., Doppelfeld 1956; Precht 1973; Hinzen and Schütte 2003), as well as damage described here for the first time in their archeoseismological context. The damage includes (1) cracked foundation walls, (2) subsided structures, (3) tilted structures, (4) opening of horizontal gaps, (5) deformed structures, and (6) a collapsed hypocaust.

The aerial photo in Fig. 1 shows the current building locations in the city center of Cologne together with the outline of the Roman and Medieval structures discussed in the following.

\subsection{Northern sewer}

The sewer north of the Praetorium (Figs. 1 and 2), part of the sophisticated Roman dewatering system of the city, was built in the first century $\mathrm{CE}$, with the western section prior to the founding of the colony (50 CE). 

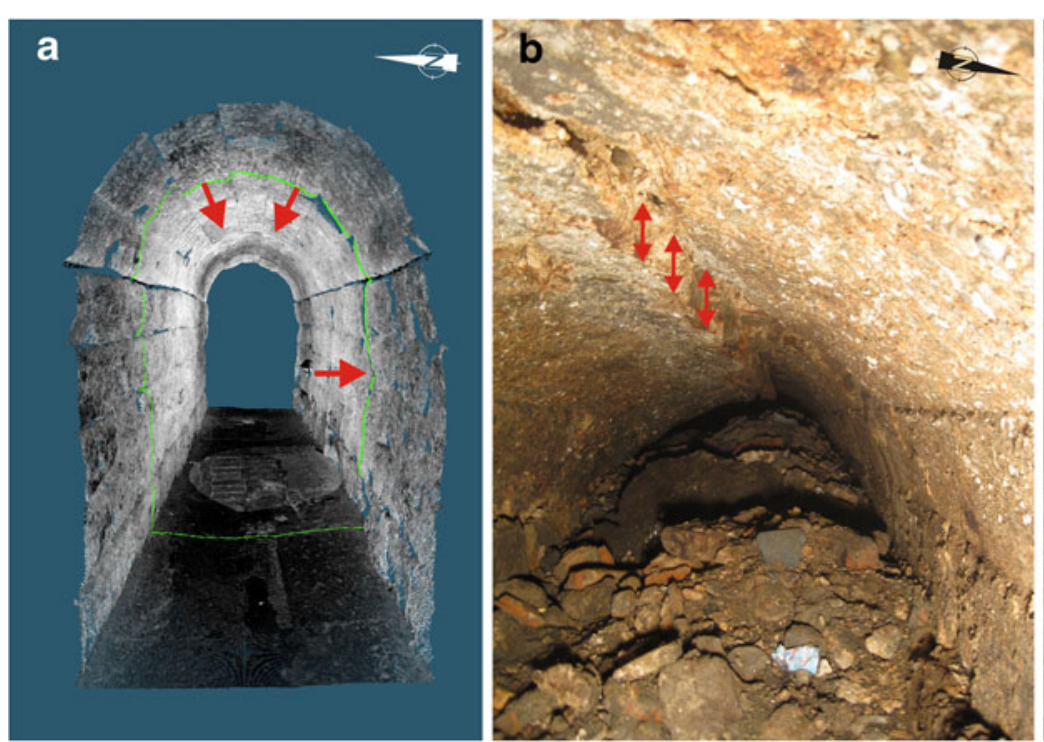

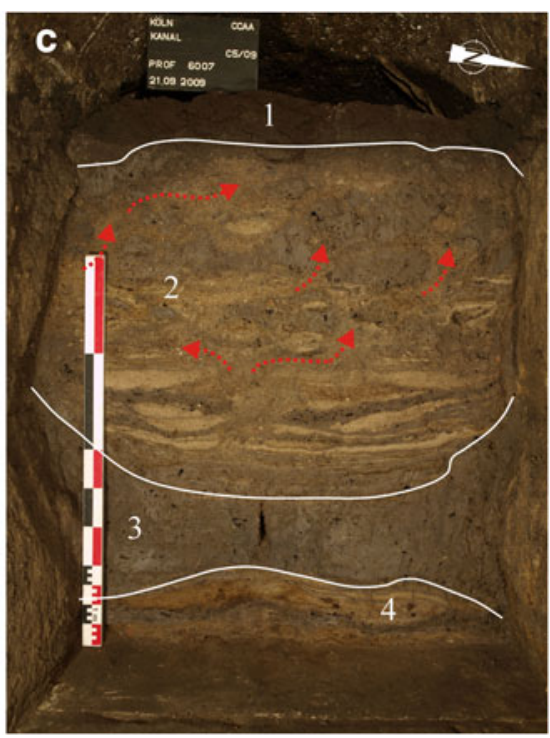

Fig. 2 a Perspective view on the virtual model of the western section of the Roman sewer in Cologne. b Photo looking west into the top of the eastern section of the northern sewer. Arrows indicate the vertical displacement along the cracked roof. c

The construction of the Roman city wall made an eastward extension of the sewer necessary. This extension is linked to the western section through a construction joint. While the roof of the western section is made from tuff blocks, opus caementicium was used in the extension. Recent excavation of sediments in the eastern section of the sewer (Fig. 2) indicates that maintenance of the sewer stopped in last quarter of the fourth century CE (Schütte und Gechter 2011) and that it was quickly filled after its abandonment with fine-grained sediments and trash. Parts of the fine-grained layers show signs of remobilization after the initial deposition (Fig. 2).

The $115 \mathrm{~m}$ long western section that is already part of the existing Praetorium museum was completely scanned with 26 single scans. The initial excavation of the eastern section had to be discontinued due to static stability concerns and only an emergency scan campaign has so far been possible. A total of 24 crosssections through the virtual model of the western sewer section were compared to a master crosscut in order to quantify any deformations. These were mainly found in the tuff block roof (Fig. 2). Several of the northern neighboring blocks of the center stone are dislocated inwards. For each cross-section, the ideal shape of the sewer at this position was reconstructed based on the width of the construction and the height
Photo of a profile through the sediment fill in the eastern section of the Roman sewer after maintenance ceased; white lines separate four deposition layers and red arrows indicate remobilisation (photo courtesy of Archäologische Zone Köln)

of the sidewalls. Inward and outward deviations of the measured cross-sections from the ideal shape were quantified through the residual areas that measure on average $6.4 \pm 2.8 \%$ of the total cross-section. If only the roof is taken into account, the residual area was found to be $9.3 \pm 5.3 \%$ of the total cross-section.

The opus caementicium roof of the eastern sewer section rests on walls made from large $0.6 \times 1.2 \mathrm{~m}$ tuff blocks. A massive crack cuts through the roof, parallel to the trend of the sewer over a length of at least $14 \mathrm{~m}$; it displaces the roof by up to $0.15 \mathrm{~m}$, and the crosssections from the CVM indicate a clockwise rotation (view to the west) of the northern half of the roof. In addition, the archeologists found several large patches of rock that were detached from the tuff blocks, mainly at the lower part of the walls. These shell-like patches were still in situ and held in position by the sediments, indicating that the detachment occurred after the sedimentation process. Patches of the roof were found on top of the Roman sediments: however, they were not sunken into these layers at all (Schütte, personal communication), also indicating a damaging event after the accumulation of the sediments. The sediments, at least in one section, show signs of reworking after the initial sedimentation (Fig. 2).

All four damage patterns (1) cracked roof, (2) displaced roof blocks, (3) detached shells of the vertical 
blocks, and (4) reworked sediments in the sewer can be interpreted as a response to dynamic ground motions during an earthquake. However, all four patterns can also have different causes. The level of the sewer shows that it was frequently flooded during high waters of the Rhine River; this happened at least five times during the past 20 years. Flood events early after the first sedimentation can have caused liquefaction without ground shaking and mobilized the unconsolidated sediments (Niemi and Marco 2011, personal communication). Martel (2011) found prominent shallow surface-parallel fractures in rock and that compression parallel to a convex surface can cause subsurface cracks to open. On the other hand, even after the maintenance stopped and the sewer was filled with sediments, it stayed constantly moist. Therefore, alteration of the tuff material due to moisture and water saturating the lower parts of the sediments can have caused the detachment of the shells (Stück et al. 2008). If parts of the roof in the eastern section broke off coseismically, they should have been found embedded in the mobilized sand of the sewer fill and not on top of it. The structural damage to the sewer might also be a consequence of recent dynamic impact from WWII bombing. An aerial photograph from April 1945 (Fig. 3) shows numerous bomb craters in the close vicinity of the sewer. All buildings north and south of the street Kleine Budengasse are destroyed, and three large bomb craters are directly above and in the immediate neighborhood of the crack in the sewer roof.

\subsection{Octagon}

The foundations of the Octagon (Fig. 4), the former 25-30 m high central part of the Praetorium (building phase IV) shows the most obvious damages among all objects in the study area. The massive $1.5-2.25 \mathrm{~m}$ wide walls are completely cracked, and the eastern section of the Octagon moved down in the direction of the natural slope. This damage was already taken by Precht (1973) and Hinzen and Schütte (2003) as a clear indication of a collapse of the upper part of the Octagon. With the CVM, we are able to quantify the details of the damage. A total of 37 cross-sections of the Octagon show inclinations of the eastern part of $9.15^{\circ}$ in maximum. Inclinations of the walls in the range of the northern hall of the Praetorium show a clear decreasing trend from east to west. The front wall

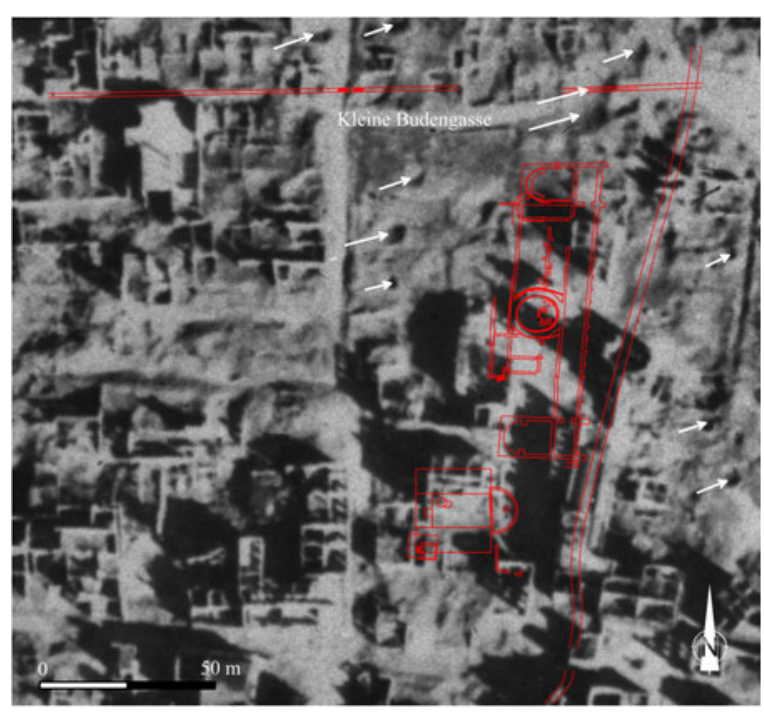

Fig. 3 Aerial photograph of Cologne taken in April 1945. The photo with an original scale of 1:7,000 was georeferenced and cropped to the same outline as the contemporary photo in Fig. 1; however, the oblique perspective was not completely compensated. Contours of major Roman and Medieval features are shown in red, the section of the Roman sewer which shows the large $14 \mathrm{~m}$ roof crack is hatched. Arrows mark bomb craters, which are best visible in the open squares and streets (photo: Luftbilddatenbank Ing.-Büro Dr. Carls, Estenfeld)

of the Praetorium phase IV (porticus gallery) is also inclined eastward (Fig. 4). This up to 2 -m wide wall is cut by cracks at three locations. The most severe crack displaces the northern part by $0.26 \mathrm{~m}$ in the vertical direction with respect to the southern side of the crack that has a horizontal opening width up to $0.3 \mathrm{~m}$. This fracturing of the foundation caused heavy structural damage of the upgoing wall and occurred at a location where a massive opus caementicium foundation in the south changes to a pile grading foundation in the north. The wall from building phase III highlighted in Fig. 4 is inclined up to $13.7^{\circ}$ between the Octagon walls and up to $15^{\circ}$ north of it. Large uncertainties exist in the timing of these events; however, a chronology is given in the discussion paragraph.

\subsection{Porticus}

The section named Porticus by the archeologists is located at the southeastern side of the study area (Fig. 5). It contains parts of the southern extension of the building phase III of the Praetorium and parts of the Medieval hospital of the Jewish quarter. Crosssection from the CVM show intact Medieval walls 


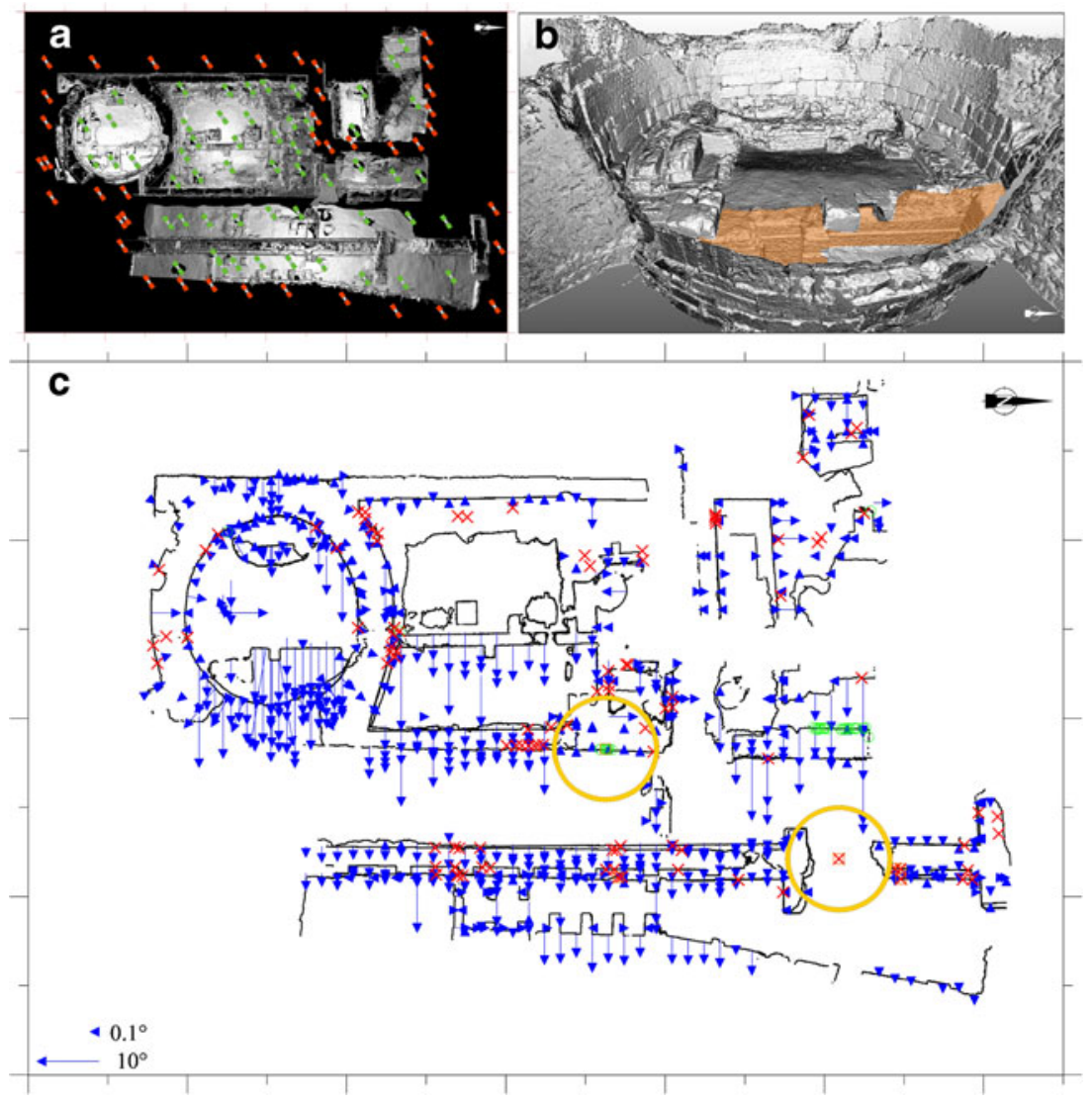

Fig. 4 a Orthographic view from above to the virtual model of the northern section of the Cologne Praetorium, the Octagon is located in the southwest corner of the figure. Red and green symbols indicate the position of 94 scanner measurement points from a higher and lower level, respectively. b Perspective view of the virtual model of the foundations of the Octagon. The colored wall section is from the third II/III building period,

built against the facade of the Praetorium of building phase III which is inclined up to $8^{\circ}$ towards east (Fig. 5). The fracture and rotation of a large tuff block of a Roman foundation wall could be identified as result of a recent anthropogenic action. Excavation photographs of the campaign in the 1950s show the block intact.

\subsection{Roman well}

The freshwater well is one of the 10 wells located in the southern part of the study area. These include wells from the Roman period as well as Medieval and more recent constructions. However, even the younger wells cut through the Roman buildings. The well under while the Octagon was built in period IV. c Result of the damage analysis of the northern section of the Praetorium. Blue arrows indicate inclination of walls or wall sections, red crosses mark the location of major cracks, green circles are horizontal gap openings, and the yellow circles include areas affected by WWII bomb explosions. A distance of $10 \mathrm{~m}$ separates major tick marcs

study, located within the apse in front of the current Cologne city hall (Fig. 6), has a depth of $13.2 \mathrm{~m}$ and is constructed from 359 trachyte blocks arranged in 36 layers. The upper $5.5 \mathrm{~m}$ of the well are in perfect condition due to rebuilding in the tenth century CE. The repair happened after the well was heavily deformed, indicated by still existing damage below this depth of $5.5 \mathrm{~m}$. With a special support system, which can be fixed pneumatically at any depth to the well (Fleischer et al. 2010), 20 scans were recorded to include the construction in the CVM.

The model shows block layer inclination towards east at angles up to $11^{\circ}$, and in addition, the circular well is deformed to an ellipse with the short axis in NW-SE direction. Best-fitting planes for the surface 
Fig. 5 a Orthographic view from above to the virtual model of the Porticus section of the excavation (see Fig. 1). Green symbols indicate the position of eight scanner-measuring points. b Perspective view towards northwest to the virtual model of the Porticus area. The colored part is inclined Roman arc wall which is shown in detail in c. The blue arrows in $\mathbf{c}$ indicate inclinations and the red crosses the location of major cracks. A distance of $10 \mathrm{~m}$ separates major tick marcs
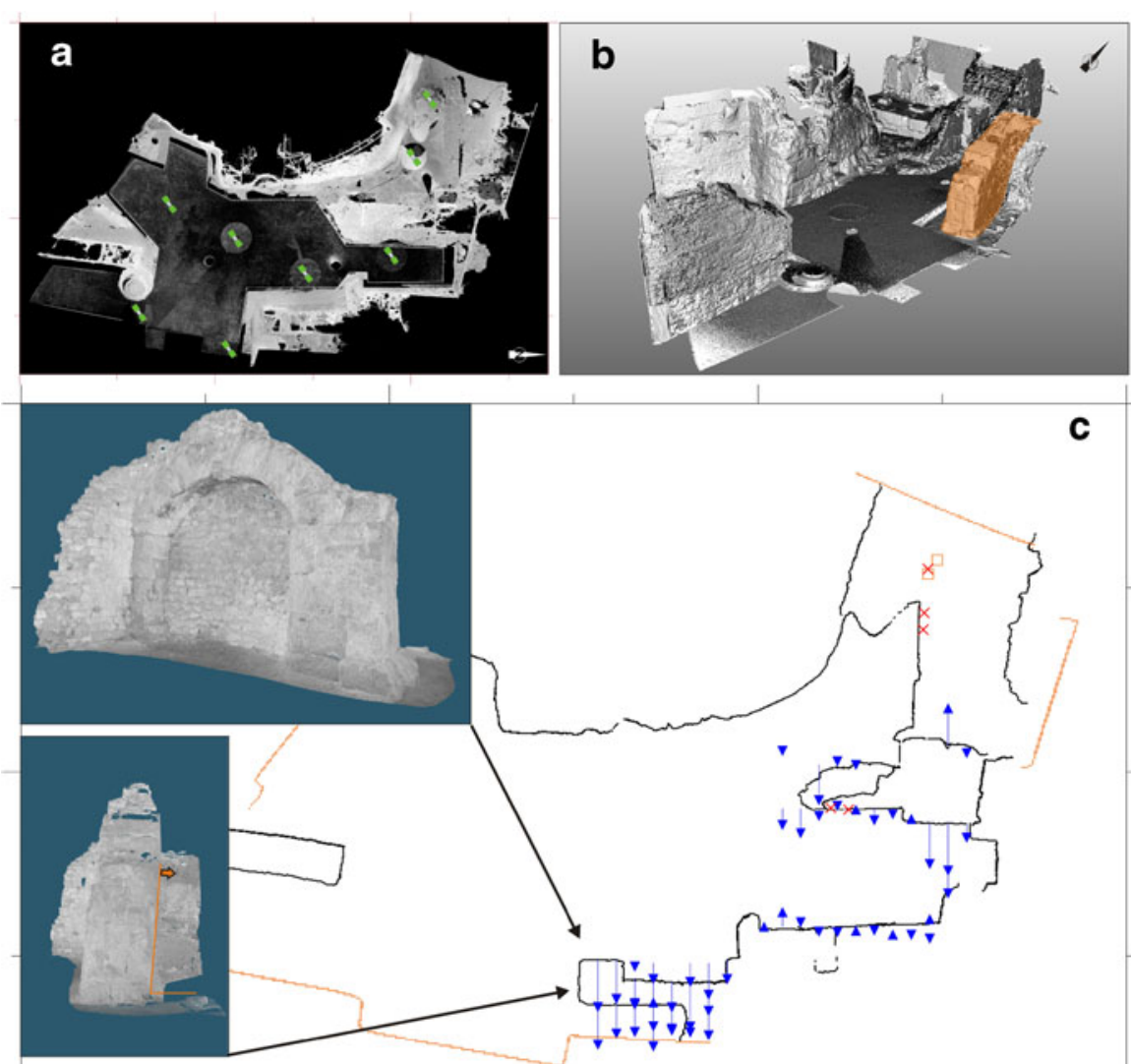

C

$4.1^{\circ}$

$10^{\circ}$ of each building block were calculated and the deviation of the plane normal from the horizontal direction determined (Fleischer et al. 2010). When the $2.5 \mathrm{~m}$ sediment fill of the well was excavated in 2008, a wooden construction was found at its base sitting in fine-grained sand. Between the completion of this excavation in 2008 to the time of the lasers canning in 2009 , the depth of the well decreased from 13.2 to $12.5 \mathrm{~m}$ due to seeping sand.

\subsection{Cesspit and hypocaust floor}

Following Schütte and Gechter (2011), the antique building in the center of the town hall square (Fig. 6) was in use in early Medieval times prior to the year $800 \mathrm{CE}$ as a synagogue. While the antique building had a central room and an adjoining northern and southern room, the synagogue was reduced to the central room after $800 \mathrm{CE}$. The walls of the central part were obviously repaired. The southern room was given up; however, the northern room was in use after some repair, indicated by a new floor found in parts of the former northern annex (Schütte and Gechter 2011).

A large cesspit located in the northwestern corner underneath the synagogue was excavated between summer 2008 and spring 2010. It has a diameter of 2.3-2.5 m, and the excavation reached the final depth of the structure at $42.97 \mathrm{~m}$ above sea level (asl). The $8.3 \mathrm{~m}$ deep cesspit built from 60 to 70 layers of small to medium tuff blocks was statically unstable and the walls had to be stabilized and reconstructed successively when the fill was removed. Schreiber et al. (2012) describe in detail the scanning procedure and implementation of the cesspit in the CVM. At a depth between 49 and 47 masl, the walls of the cesspit are heavily deformed and damaged. The severity of deformation indicates that only fill in the cesspit prevented the structure from a collapse. The fill is archeologically dated to the middle of the fourteenth century, giving a terminus ante for this damage. At the bottom 
Fig. 6 a Orthographic view from above to the virtual model of the eastern section of the Medieval synagogue, the apse, and the Porticus area (see Fig. 1). The green symbols indicate the positions of individual laser scans. Major tick marcs are separated by a distance of $10 \mathrm{~m}$. b Orthographic view from south to the cesspit of the synagogue. The heavily damaged section between 47 and 49 masl is shown unrolled in c. Here, color is superposed on the virtual model and the red arrows indicate deformation of 348 individual tuff blocks. $\mathbf{d}$ and e Perspective views towards the virtual model of the apse, before and after the start of the excavations, respectively. In between $\mathbf{d}$ and e an orthographic view from south to the Roman well is shown (Fleischer et. al. 2010)
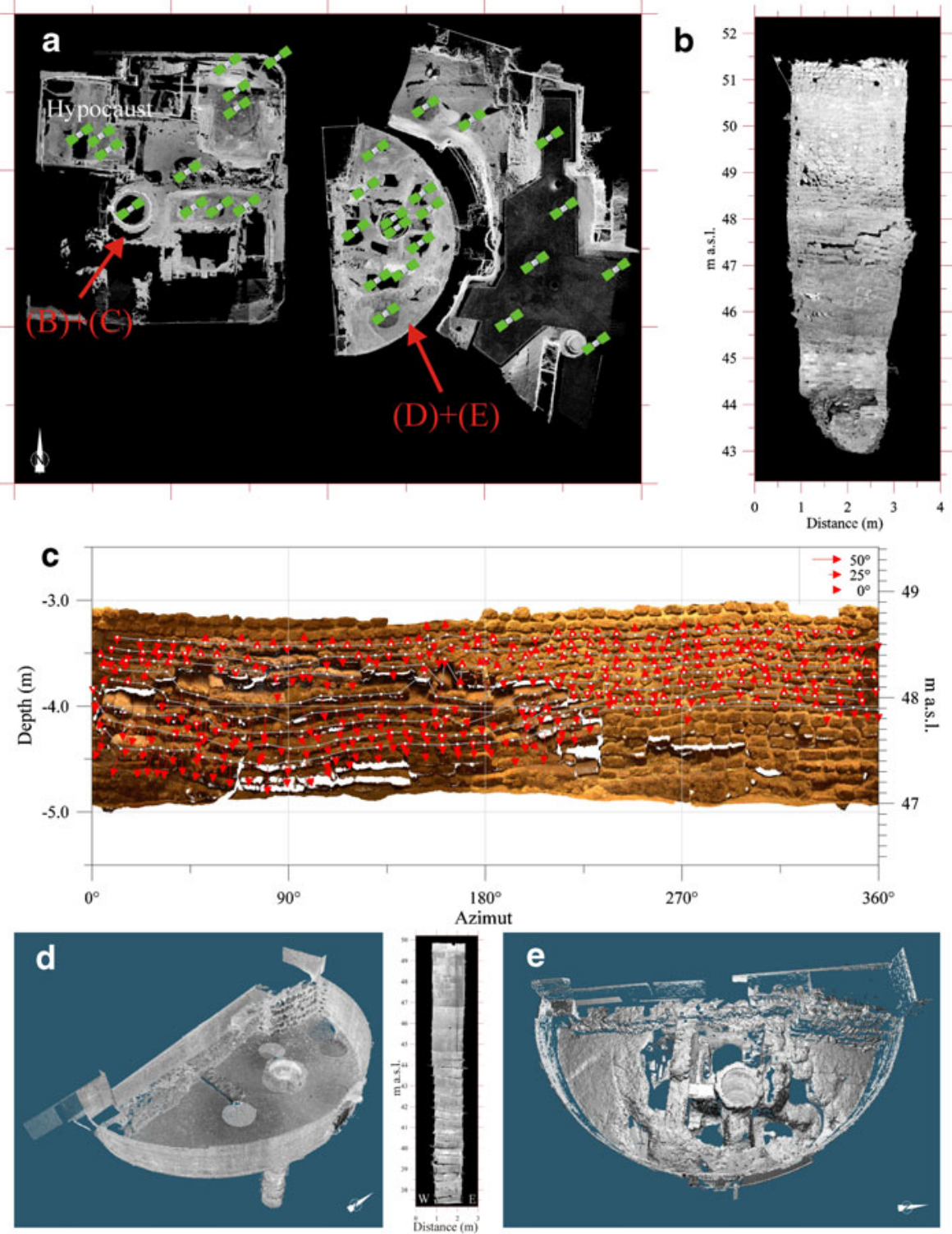

of the cesspit, the same kind of sand exists which was found behind the cesspit walls and beneath a neighboring profile of a collapsed hypocaust floor.

The colored scan in Fig. 7 reveals the following stratigraphy of the collapsed floor (from bottom to top): (1) fine sand of minimum $0.8 \mathrm{~m}$ depth extension as derived from two auger cores and (2) clay layer of $0.5-0.6 \mathrm{~m}$ thickness. It is not clear whether the clay layer is a natural deposit or whether it was embedded (possibly in Roman times) for leveling purposes. The clay is overlain by (3) a foundation of basalt fragments that support the (4) $0.1-0.15 \mathrm{~m}$ thick pavement from the end of the first century CE. On top of this early antique pavement, a second, $0.05-0.1 \mathrm{~m}$ thick, late antique pavement follows. This pavement is overlain by the (5) rectangular hypocaust tiles stacked to pillars with a height of $0.8-0.9 \mathrm{~m}$. Above the (6) broken floor, remnants are preserved (7) bluestone tile floor fragments. On top of this, destroyed hypocaust structure a $0.3-0.7 \mathrm{~m}$ thick (8) leveling layer was placed and a (9) Carolingian floor is the profile top. The concave bending and inclination of $12^{\circ}$ of unit (4) indicates a substantial subsidence on the northern side of the profile. A sample from the loam layer beneath 


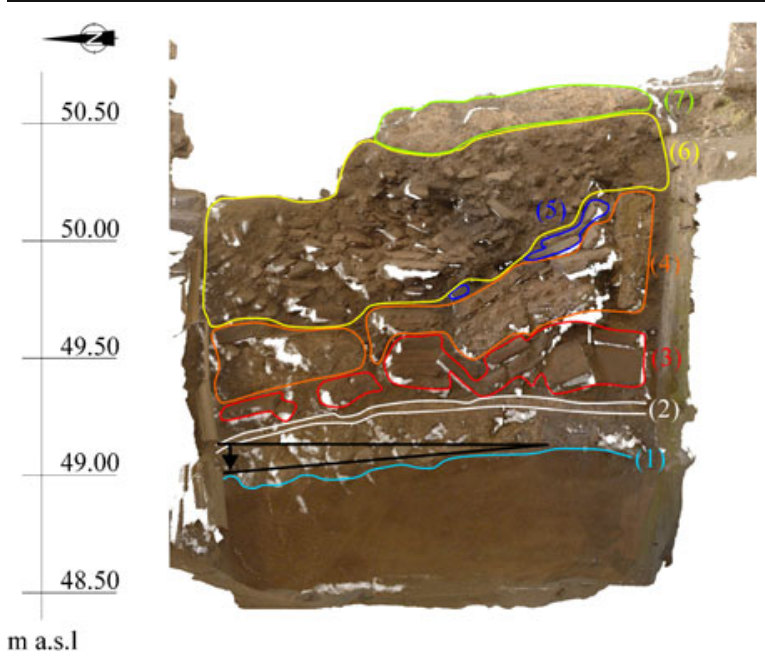

Fig. 7 Virtual model of a profile through the collapsed hypocaust system under the synagogue floor. The colored lines indicate: 1 top of the naturally deposited loam, 2 Roman screed, 3 collapsed hypocaust tiles, 4 remains of the hypocaust ceiling, 5 former tiles of the heated floor, 6 rubble, and 7 screed of repair floor. The black arrow indicates the tilt of the late antique pavement

the floor was radiocarbon dated with $93 \%$ probability to 809-980 calCE calibrated with OxCal v4.1.7 (Bronk Ramsey 2009; Reimer et al. 2009; Rethemeyer 2011, personal communication). This physical dating result is in contrast with the archeological context that requires a deposition of this layer prior to the first Roman floor.

In the northeastern corner of the former northern room of the synagogue (Fig. 1) a pit was found and is still being excavated during the compiling of this paper. The pit was filled with debris, archeologically dated to the pogrom of 1349. At 48-49 masl, a massive foundation, possibly Roman concrete, is overlain by a Medieval wall. The concrete foundation is in places broken and inclined (Fig. 8) causing a collateral deformation of the Medieval block wall. This location was where, ca. $1000 \mathrm{CE}$ (Schütte and Gechter 2011), the women's synagogue was built as an annex to the main synagogue building in the south. The pit's fill clearly indicates that some sort of basement existed underneath the women's synagogue. A C14 sample was taken from the soil about $40 \mathrm{~cm}$ behind the broken base (Fig. 8) using a sample liner. The sample was dated to $855-975$ calCE with $84 \%$ probability. This can be assumed as the period during which at least the Medieval top part of the structure in Fig. 8 was built, as the sample originates from the trench necessary to build the wall. Assuming that this wall was intact when the women's synagogue was built on top of it, the damage must have occurred after $1000 \mathrm{CE}$.

\subsection{Mikveh}

The $14 \mathrm{~m}$ deep mikveh (Fig. 1) reaches down to a level of 36.7 masl. The main shaft is rectangular with a size of $4.1 \times 3.7 \mathrm{~m}$. The shaft shows a small inclination towards south of $1.5^{\circ} \pm 1.4^{\circ}$ on average. The base of the basin in the mikveh is deep enough to hold fresh ground water, usually throughout the whole year. It sits directly on fine-grained sand. North of the shaft at a level of 45.6-48.5 m asl, two walls, probably part of a former entrance, show heavy structural damage due to subsidence (Fig. 9). The original positions of the horizontal tuff block layers including a single and a double supporting arch on the east and west side, respectively, could be reconstructed on the basis of the CVM. The arches are subsided $0.4 \mathrm{~m}$ at their southern end. The single arch in the east and the upper
Fig. 8 a Virtual model of the structurally damaged wall at the northeastern side of the pit underneath the women's synagogue (Fig. 7). The virtual planes (gray) were used to quantify the tilting of the structures. The arrows indicate the location of cracks. b The location of the radiometric dating sample
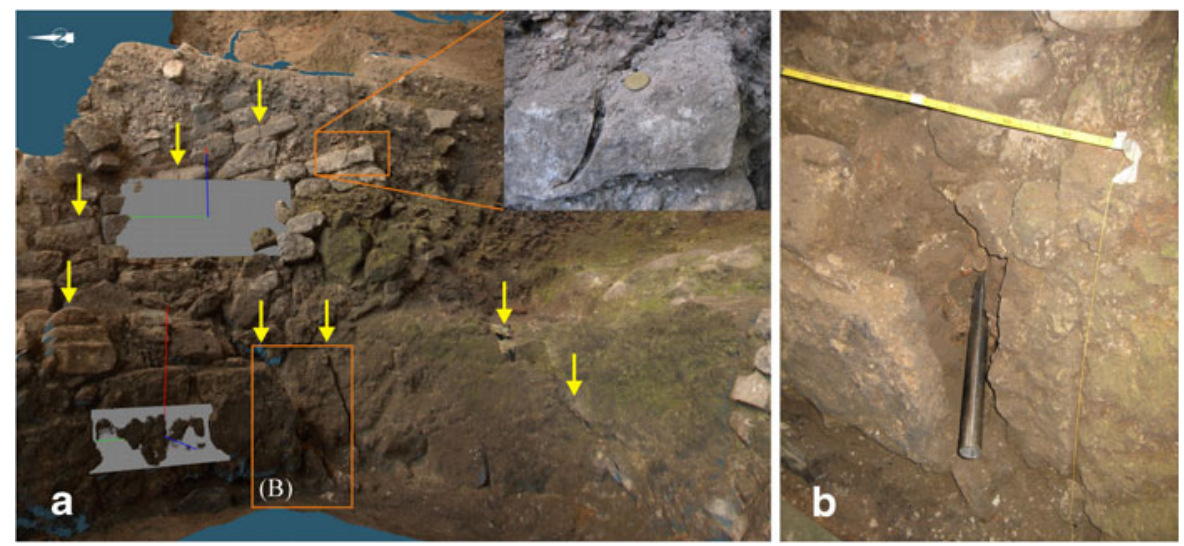
Fig. 9 a Perspective view from northwest towards the virtual model of the Medieval mikveh. The top section is formed by the modern protective construction of a glass pyramid and an entrance room proceeding downwards via the staircase and the basin. The dashed yellow line indicates a section of the wall that was cut away from the model to allow the view inside the staircase. b Orthographic view from above to the mikveh; major tick marks are separated by a distance of $5 \mathrm{~m}$. Green symbols indicate the position of individual scans, and the red labels correspond to the two orthographic views of the eastern (c) and western (d) wall of the former entrance to the mikveh. In $\mathbf{c}$ and $\mathbf{d}$, the colored lines indicate corresponding sections of the damaged walls
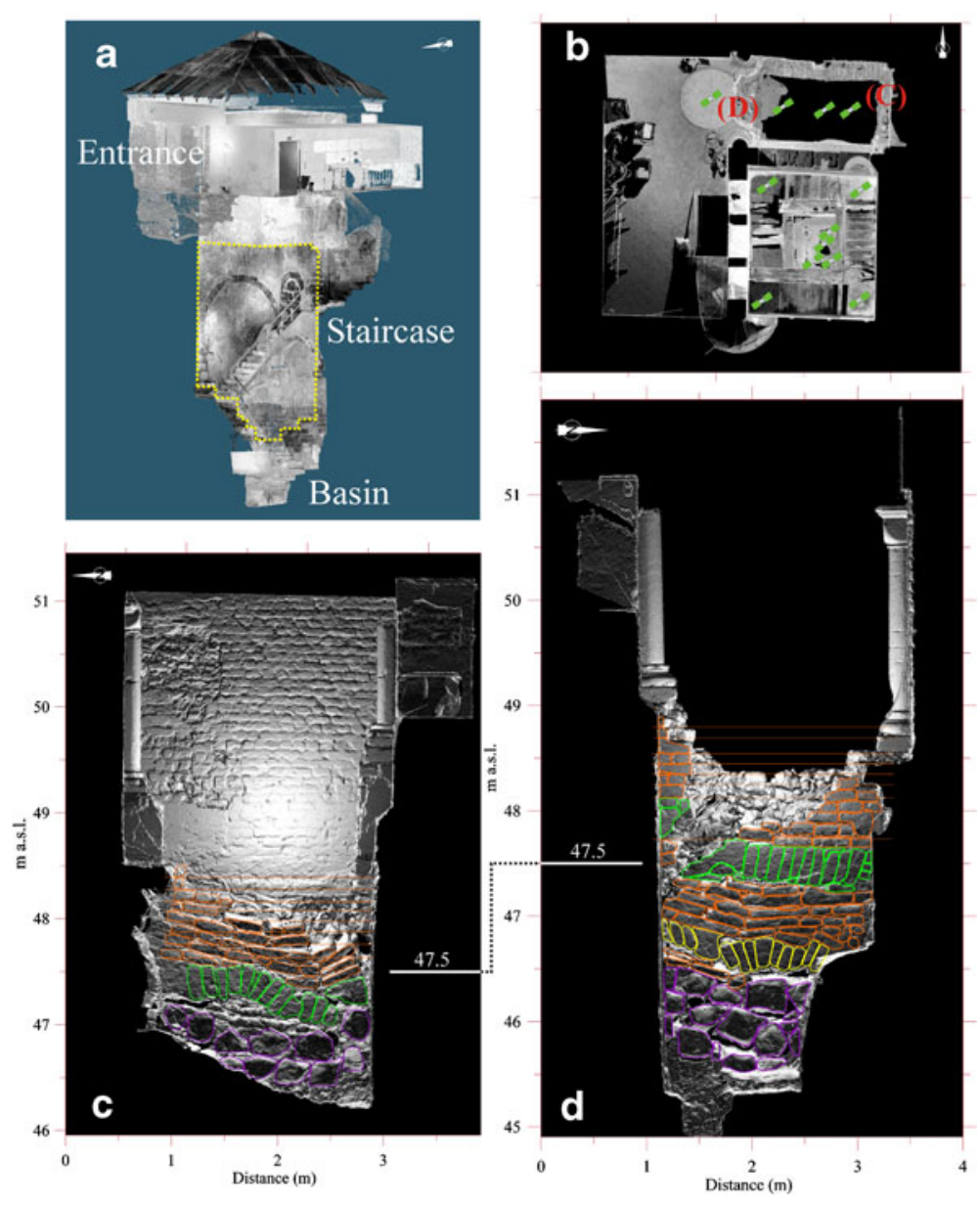

arch in the west are at the same height. Below the upper western arch the wall continues downward with a masonry section of $0.5 \mathrm{~m}$ and a second arch. With a distance of $3.5 \mathrm{~m}$ between the walls, this might be an indication that the arches are the tops of a ca. $8^{\circ}$ inclined former entrance pathway; however, a proof of this assumption would require deeper excavation, which is difficult due to the static conditions. The northern end of the arches was found to rest in loose sediments without any foundation; no explanation has been found for this so far.

Large basalt columns were found horizontally layered underneath the arch on the east and underneath the second, lower arch on the west side. These basalt columns were probably not part of the original construction but could have been placed to support the subsided (or subsiding) structures. On top of the damaged section, several floor levels were built at elevations between 47.2 and 47.7 masl. These date to the time between the eleventh and fourteenth century CE.

\subsection{Damage pattern}

All damage listed above directly involves or is at least compatible with strong subsurface deformations within the slope and artificial fill in which the structures are found or directly related to fine isolated sand lenses. If they were of seismogenic cause, the damage must therefore be classified as secondary damages as already indicated by Hinzen and Schütte (2003). Typical primary vibration-induced damage (i.e., Galadini et al. 2006; Hinzen 2011) such as corner stone expulsion, shear wall cracking, and toppled walls have not been found in the study area. The damage patterns as recorded in the CVM are either within the range of the slope of the river terrace, i.e., Praetorium, parts of the sewer, the Porticus, the apse with the Roman well, or on top of the terrace, i.e., synagogue buildings with the cesspit, mikveh, and Medieval residential buildings. While the former include mainly tilted constructions, the latter are all 
primarily consequences of subsidence. However, the block displacements in the western section of the northern sewer, the cracked roof of its eastern section, and the reworked sediments do not fit into the damage patterns listed above.

\section{Subsurface}

The current morphology in the central part of Cologne city shows only weak traces of the original depositional environment before the city development began over 2,000 years ago. In some sections, more than $10 \mathrm{~m}$ of artificial fill overlies the natural deposits. Our new model is based on 358 elevation data of the natural ground from boreholes, auger cores, and trenches or archeological excavations and is based on the previous model by Hinzen and Schütte (2003), the data presented by Holthausen (1994) and numerous sources are listed in Table 1. The model comprises $0.9 \mathrm{~km}^{2}$ of the Cologne city center. Figure 10 shows a perspective view of the digital terrain model formed by the Lower Terrace deposits in the center of Cologne. It includes the eastern part of the CCAA and is from west to east structured into the Lower Terrace plateau (the location of the flood-safe Roman colony), the former side arm of the Rhine River, and a peninsula. At the easternmost edge, the model includes the course of the Rhine River. The model was created by a standard Kriging technique.

Heavy anthropogenic alterations of the relief introduce uncertainty into the reconstruction of the original structure. In addition, the auger cores do not always lend themselves to a ready differentiation between naturally deposited and anthropogenic reworked flood loam. The area inside the Roman city wall (Fig. 10) is $47-52$ masl corresponds to $8-14 \mathrm{~m}$ above the average Rhine River level at Roman times at 38.86 m (Köhler 1941). This level is only $4 \mathrm{dm}$ higher than the current average level of 38.46 masl (STEB 2009). The side arm of the Rhine River was connected to the actual riverbed at the northern end. It has been intensively debated in the literature whether a harbor existed in this sidearm of the river at Roman times (i.e., Schultze et al. 1885; Lückger 1919; Köhler 1941; Doppelfeld 1953; Hellenkemper 1980; Wolff 2000). The model presented in this paper does not show a connection to the riverbed at its southern end, and with an average water depth of 1.87-3.65 m, it would have been only accessible by boat from the
Table 1 Source, type, and number of data used for the construction of a digital terrain model of the study area

\begin{tabular}{llr}
\hline Source & Type & Number \\
\hline Holthausen (1994) & M, A, B & 161 \\
Erdbaulaboratorium Essen (1998) & B & 28 \\
Institut Geotechnik Offer (2000) & B & 10 \\
Erdbaulaboratorium Essen (2002) & B & 91 \\
Erdbaulaboratorium Essen (2005) & B & 26 \\
Umwelttechnik (2008) & B & 33 \\
Seismogical Station Bensberg (2009) & B & 4 \\
Tillsmanns and Partner GmbH (2009) & B & 5 \\
& Total & 358 \\
\hline
\end{tabular}

$M$ map, $A$ archeological excavation, $B$ borehole

northern opening. However, accessibility during lowwater levels of the Rhine River is questionable if no dredging of the flood loam at the entrance was made.

A profile from west to east through the elevation model at the location of the town hall square was used to construct a 2D finite element model of the subsurface that was later used to study slope stability and seepage effects of rain water (Fig. 11). The layers include Tertiary sediments, Quaternary deposits of the Lower Terrace, flood loam, side arm fill, and artificial fill on top of the slope. Table 2 shows the key geotechnical properties of these materials based on Erdbaulaboratorium Essen (2002, 2005), Budny (1984), the engineering geological map of Cologne (Geologisches Landesamt NRW 1986), and laboratory and in situ testing during this study. The relations between shear modulus and damping to strain (Kramer 1996) for these materials were taken from Seed and Idriss (1970) and Vucetic and Dobry (1991). The depth extent of the fine sand layers correlates with the observations made in the archeological excavation. This model was used for static and dynamic slope stability studies and for a seepage analysis as described below.

\section{Earthquake ground motion model}

\subsection{Seismotectonic model}

Based on a model of active faults in the LRE, which Hinzen (2005a) used in an archeoseismological study of the Roman fortification walls of Tolbiacum, the updated model shown in Fig. 12 was derived. In this 


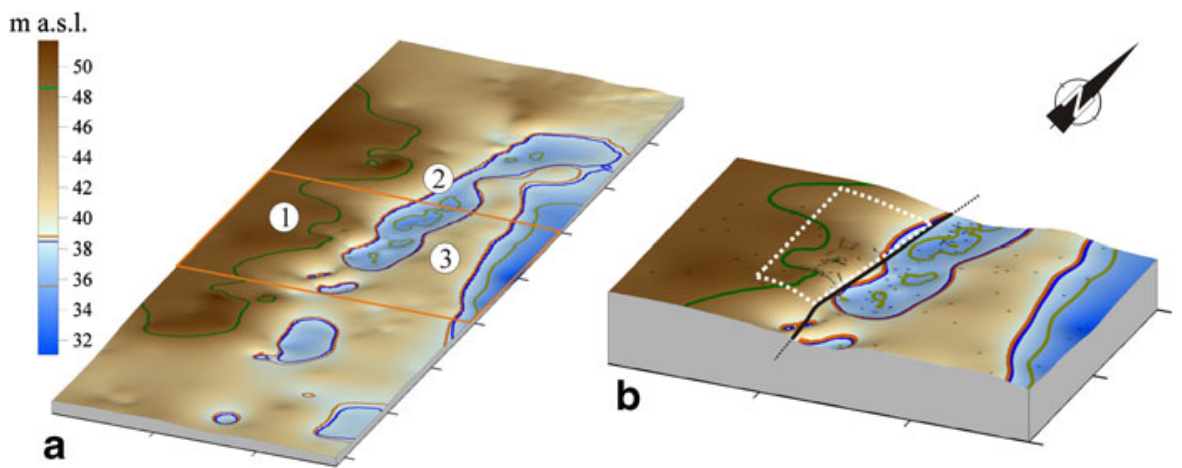

Fig. 10 a Perspective view of the digital elevation model; the section marked by the orange rectangle is shown enlarged in $\mathbf{b}$. 1, 2, and 3 indicates the Lower Terrace, the former side arm of the river, and the (pen-)insula east of the Roman city, respectively. The colored isolines indicate water levels of the Rhine River: green flood level of 1784 (maximum recorded level of all

current model, faults on the eastern side of the Rhine River have been included. Relocated earthquake hypocenters from the so-called Pulheim series in 1977 with a maximum magnitude of $\mathrm{M}_{\mathrm{L}} 3.7$ and five earthquakes east of the Rhine River since the year 2000 with maximum $\mathrm{M}_{\mathrm{L}}$ of 1.6 are an indication of recent activity. Due to the close proximity of these faults to the studied objects, they were considered in a worst-case scenario, though it is not certain whether these were active during Quaternary times (Vanneste et al. 2012). A total of 16 fault segments assumed active and possibly responsible for earthquakes with magnitudes above 6, labeled S01-S16 in Fig. 12 was selected for the deterministic calculation of the dynamic load in the times), orange average level during Roman times (Köhler 1941), blue current average level, and olive low level in 2003 (STEB 2009). The dotted rectangle indicates the study area and the straight black line shows the trend of the Roman city wall. Tick marks are separated by a distance of $200 \mathrm{~m}$. Black crosses show the location of data points in the study area

study area. Table 3 lists source size and location with respect to the site. The range of moment magnitudes, from $M_{\mathrm{W}}$ 6.36-6.97, agrees with published estimates of the maximum $\mathrm{M}_{\mathrm{W}}$ for earthquake in the Lower Rhine Embayment (i.e., Ahorner 2001; Schmedes et al. 2005; Hinzen and Reamer 2007). Even though earthquakes of this size have return periods of more than 5,000 years (Ahorner 2001; Hinzen and Reamer 2007), they were used as "worst cases" for the deterministic modeling of the slope stability. All earthquakes were assumed to be normal faults with a bilateral rupture and a rupture velocity of $2.0 \mathrm{~km} / \mathrm{s}$. For all modeled fault segments, a complete rupture has been assumed.

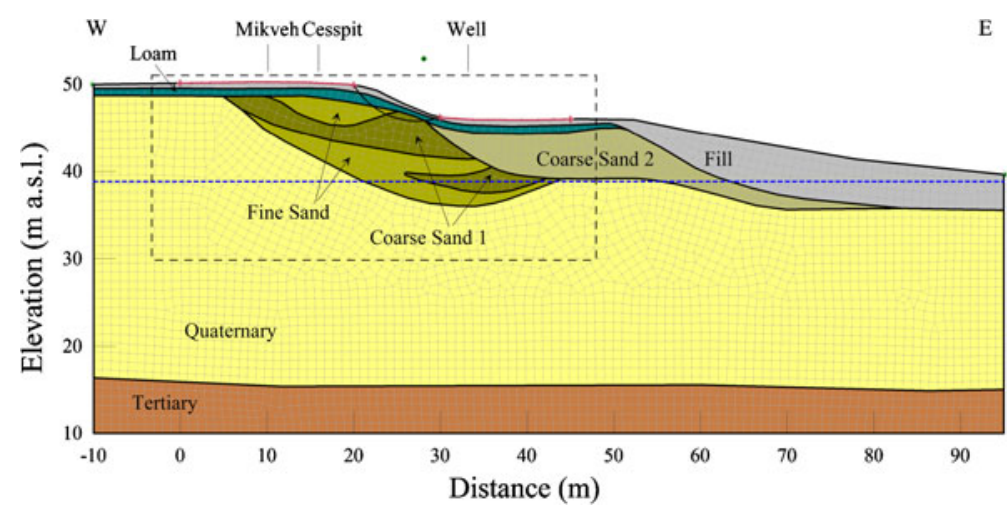

Fig. 11 2D geotechnical model of a west-east section through the study area. The deposited material is indicated by color, the geotechnical parameters are given in Table 2. The dashed blue line indicates the ground water table at $38.86 \mathrm{~m}$. The black arc indicates the slip surface with the smallest FS among the 729 tested; entry and exit points of the 729 slip surfaces were placed along the red lines; the green dot shows the center of the circular slip surface. The gray mesh shows the finite elements used in the dynamic calculations. The dashed rectangle indicates the part of the model which is shown in detail in Fig. 17 
Table 2 Material parameters of the seven layers of sediments used in the geotechnical model of the subsurface (Fig. 11)

\begin{tabular}{lccccc}
\hline Unit & Specific weight $\left(\mathrm{kN} / \mathrm{m}^{3}\right)$ & Poisson's ratio & Cohesion $(\mathrm{kPa})$ & Internal friction angle $\left({ }^{\circ}\right)$ & $k($ at saturation) $(\mathrm{m} / \mathrm{s})$ \\
\hline Anthropogenic fill & 17.00 & 0.21 & 0 & 27.0 & $5.00 \mathrm{E}-03$ \\
Flood loam & 18.00 & 0.23 & 20 & 25.0 & $5.00 \mathrm{E}-08$ \\
Fine sand & 14.50 & 0.33 & 0 & 32.0 & $1.00 \mathrm{E}-03$ \\
Coarse sand 1 & 19.00 & 0.25 & 0 & 33.0 & $5.00 \mathrm{E}-03$ \\
Coarse sand 2 & 19.00 & 0.25 & 0 & 33.5 & $5.00 \mathrm{E}-03$ \\
Quarternary & 20.50 & 0.21 & 0 & 36.0 & $2.00 \mathrm{E}-02$ \\
Tertiary & 19.00 & 0.21 & 0 & 35.0 & $5.00 \mathrm{E}-03$ \\
\hline
\end{tabular}

\subsection{Ground motion}

Synthetic seismograms were calculated with the procedure suggested and implemented by Wang (1999). The elastic Green's functions from a 1D half space are first calculated, and in a second step, three-component seismograms for an extended earthquake source are derived. The Green's functions were determined for 101 discrete distances from 0 to $200 \mathrm{~km}$ and 50 depths from 1 to $41 \mathrm{~km}$. The parameters of the layered earth model (Fig. 13) below the Moho were taken from PREM (Dziewonski and Anderson 1981) and the crustal structure follows a 1D model optimized for the northern Rhine area (Reamer and Hinzen 2004). Site effects of the upper $40 \mathrm{~m}$ were not taken into account because these are part of the finite element model used to study the slope stability. The corner frequency of the source spectrum was set to $20 \mathrm{~Hz}$ and a rupture velocity of $2.0 \mathrm{~km} / \mathrm{s}$ was used.
Figure 14 shows the peak ground acceleration (PGA) and the significant strong motion duration for the three ground motion components and all 16 earthquakes. The latter is the time-span between exceeding $5 \%$ and reaching $95 \%$ of the total Arias intensity (Kramer 1996). The values are in a range from 11 to $28 \mathrm{~s}$, and PGAs are from 0.15 to $11.6 \mathrm{~m} / \mathrm{s}^{2}$. The latter is reached in the EW component for earthquake S04, the one with the smallest distance to the fault line; however, it is not known if this fault was active in the Quaternary.

\subsection{Slope stability}

The 2D FE model (Fig. 11) was used to study (1) the static slope stability, (2) the deformation of the slope during earthquake ground motions, represented by the strong motion synthetics described above, and (3) the possible permanent deformation during shaking
Fig. 12 Seismotectonic model of the Lower Rhine Embayment. Circles give the seismicity 1975-2010 following the catalog of the Seismological Station Bensberg (Reamer and Hinzen 2004; Hinzen and Reamer 2007). The gray lines show the major faults of the sedimentary basin. Heavy black lines labeled S01 to S16 are segments assumed as single seismic sources. The parameters of these sources are given in Table 3 . The white star shows the location of the study area in the city center of Cologne

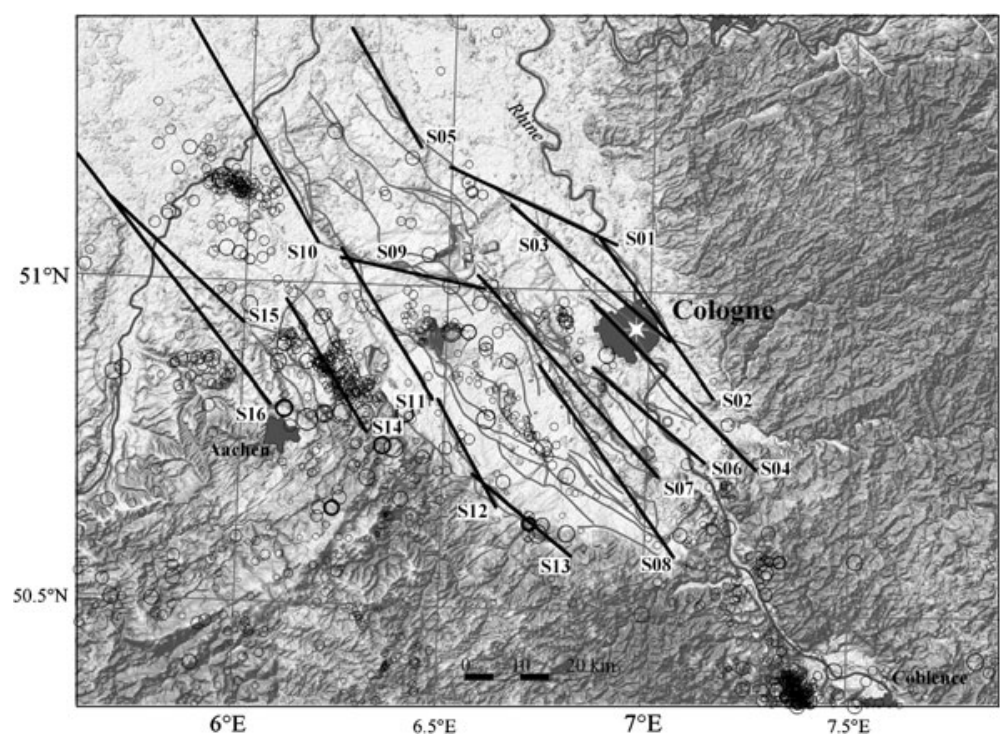




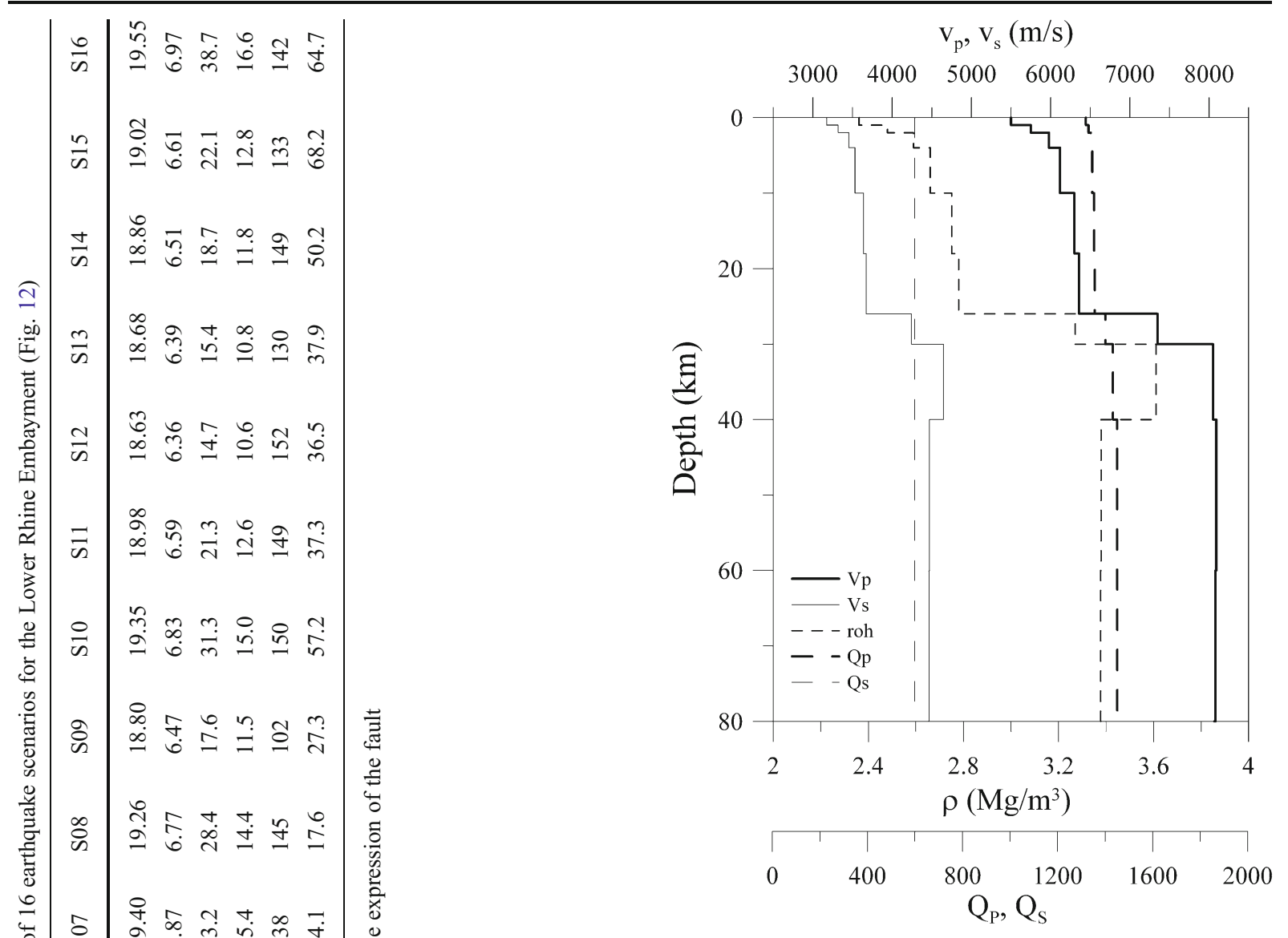

Fig. 13 Distribution of P-wave velocity, $v_{P}, S$-wave velocity, $\mathrm{v}_{\mathrm{S}}$, density, $\rho$ and Q-factors for P- and S-waves, $\mathrm{Q}_{\mathrm{P}}$ and $\mathrm{Q}_{\mathrm{S}}$, respectively, in the $1 \mathrm{D}$ model used to calculate Green's functions. The parameters follow PREM (Dziewonski and Anderson 1981) and Reamer and Hinzen (2004)

including, (4) the time-dependent variation of the factor of safety (FS) for all earthquake scenarios. The calculations were made with the commercial Geostudio 2007 software (GeoStudio 2007). The initial stress conditions were calculated with the ground water table assumed at 38.9 masl. A total of 729 potential circular slip surfaces were considered, and the range of entry and exit points is shown in Fig. 11. The sliding masses were divided into 30 vertical slices. For each slice, the resulting sum of driving and resisting forces is calculated (Kramer 1996). Slope stability is expressed through the FS which is 1.0 when equilibrium between driving and resisting forces exists and FS $>1.0$ if the sliding block is stable. The minimum value for all included slip surfaces is 2.541 indicating stable static conditions far above the limit 
Fig. 14 Peak ground accelerations $(P G A)$ and significant durations $(S D)$ for the 16 earthquake scenarios shown in Fig. 12 and listed in Table 3

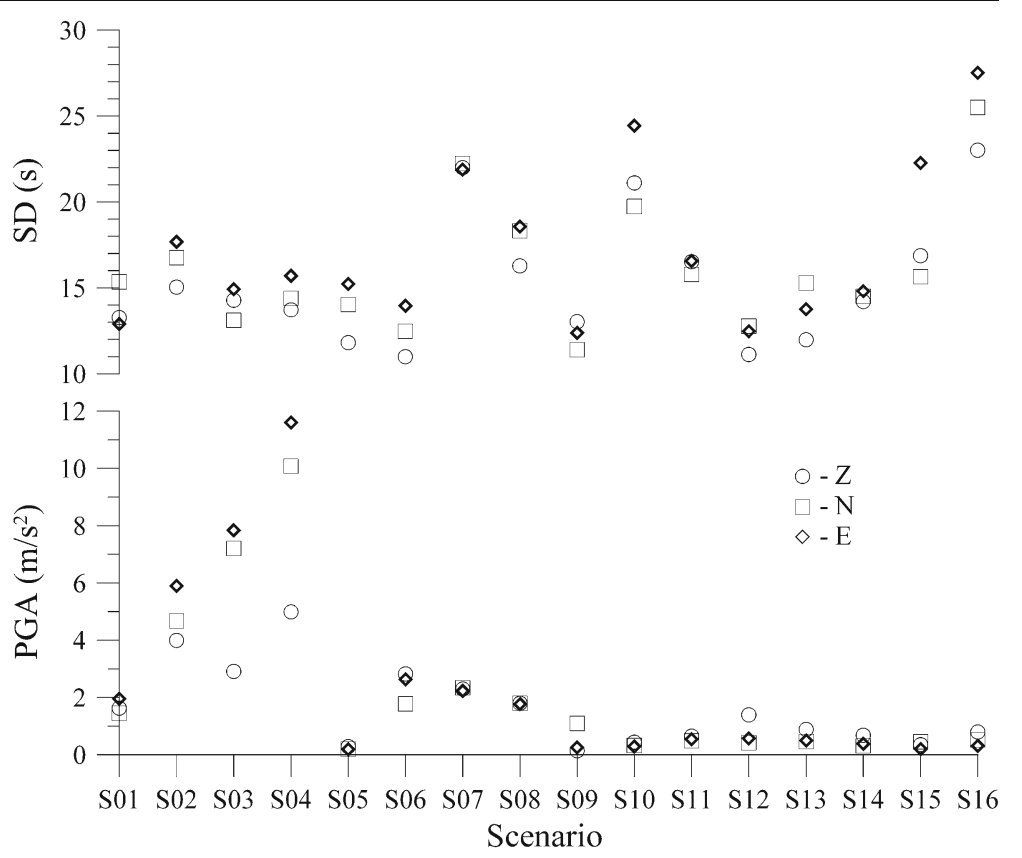

equilibrium. The slip surface with the minimum FS and a radius of $8.6 \mathrm{~m}$ is shown in Fig. 11.

The static analysis of the slope was complemented by a dynamic calculation. Earthquake ground accelerations alter the ratio of driving and resisting forces of potential slip surfaces (Kramer 1996). Depending on the amplitude and direction of the ground motion, static FS may be increased or decreased. When the FS falls below 1.0 during shaking, permanent deformations occur. The ground accelerations for the 16 earthquake scenarios were applied to the base of the 2D FE slope model. The EW component was applied in the horizontal direction combined with the vertical motion. The vertical model boundaries were fixed in the vertical directions and free in the horizontal direction. Figure 15 shows the FS as a function of time for the slip surface with the lowest FS value under static conditions for the 16 scenarios. The smallest FS reached during the shaking is between 2.223 for scenario S09 and 1.426 for scenario S04, corresponding to a reduction of $13-44 \%$, respectively (Fig. 16). As expected, the minimum FS values roughly scale with the PGA. However, even for the simulated $\mathrm{M}_{\mathrm{W}} 6.78$ earthquake S04 with a PGA exceeding $1 \mathrm{~g}$, the FS stays well above 1.0 indicating a stable slope even under extreme ground motion conditions. In addition to the FS, excess pore water pressure was monitored during shaking to detect possible liquefaction in the slope model.
With the water table at the average Rhine River level, no liquefied sections were observed.

\section{Hydrological model}

As stated above with the exception of the northern sewer, all other damage throughout the study area involved a downward movement, partial downward movement, or predominantly eastward inclinations of structural elements. In addition to compaction and/or liquefaction of loose sediments during earthquake shaking, seepage-generated suffusion and erosion can also induce settlement of surface structures (e.g., Crosta and di Prisco 1999; Farifteh and Soeters 1999; Jones 2004). Unconsolidated isolated sand lenses lacking cohesion require special attention. For seepage through these layers, the fine fraction can

Fig. 15 Factor of safety for the slip surface shown in Fig. 11 as a function of time for 16 earthquake scenarios (see Fig. 12) indicated by the labels in the upper right corner of each plot. The time windows are $30 \mathrm{~s}$ for all plots; in order to include the significant ground motions, the starting time varies. The numbers on the bottom left give the time delay between the source time and the start of the FS graph in seconds. The difference between the actual time-dependent FS and the equilibrium of $\mathrm{FS}=1$ is indicated by the gray-shaded areas. The numbers in the bottom right corner show the minimum FS during the shaking of the slope 

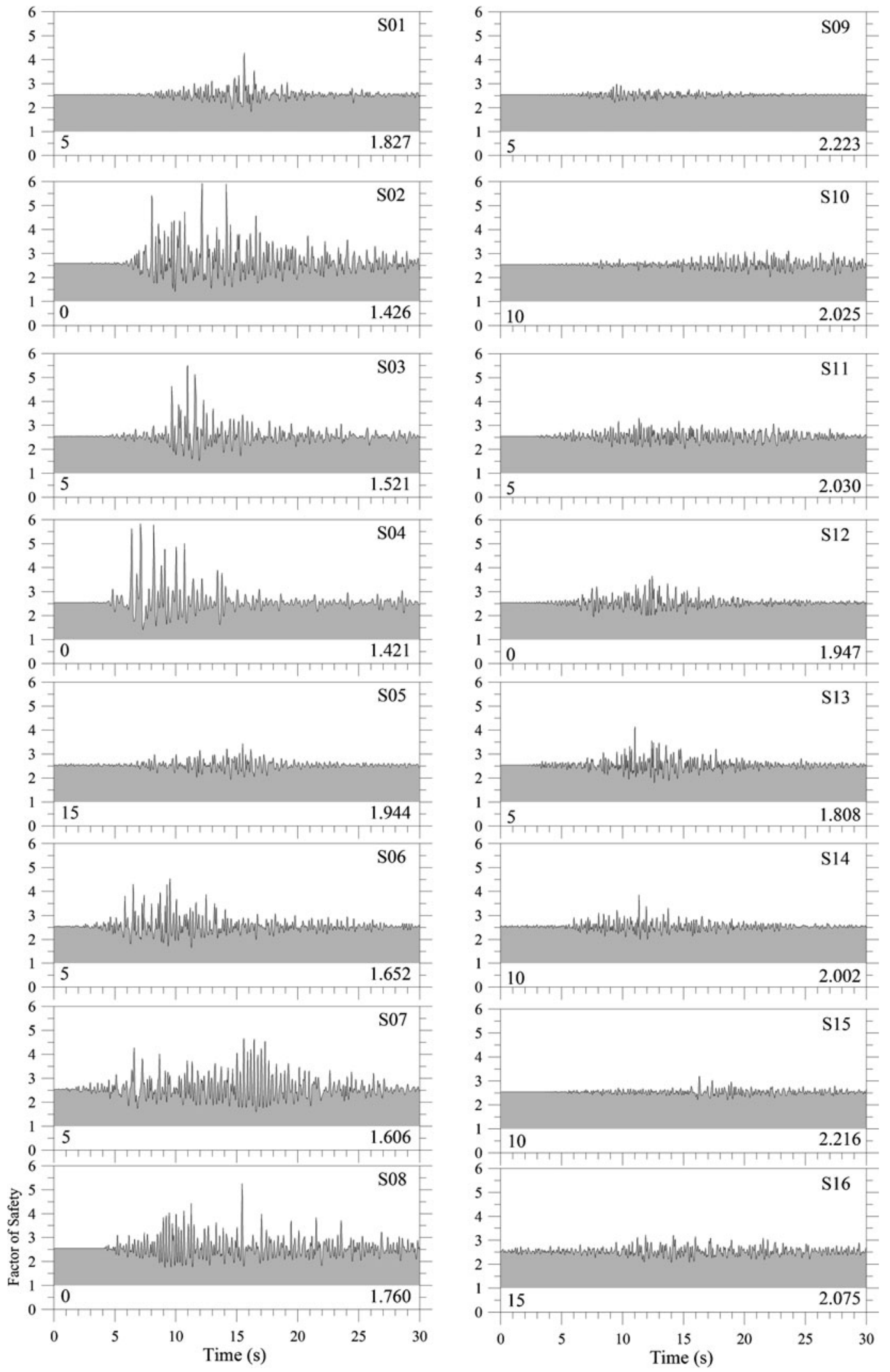


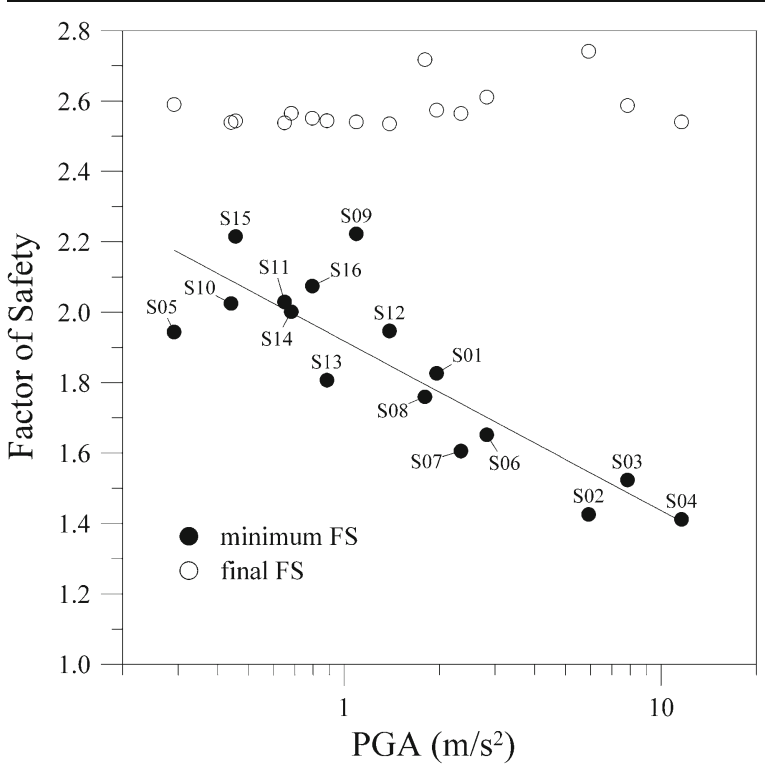

Fig. 16 Factor of safety (FS) for the statically least-stable slip surface versus the peak ground acceleration for 16 (labels) earthquake scenarios. The final factors of safety are those determined for the slope after all earthquake ground motions have ceased; the minimum FS are the smallest values reached during the shaking (compare Fig. 15)

easily be mobilized and transported to the underlying gravel-sand layers by contact suffusion. Prior to major construction and/or significant alterations of the subsurface due to human activities, the flood loam prevented penetration of large amounts of water into the slope during rainstorm events. However, with numerous construction pits cutting through the loam, more and more potential flow paths were created. In order to investigate the hydraulic characteristics of the slope, the 2D model (Fig. 11) was extended to a seepage analysis (Fig. 17). The conductivity of the material is based on the geotechnical map of Cologne (Geologisches Landesamt NRW 1986) and is listed in Table 2.

Rainstorm events were simulated by implementing boundary conditions for the model surface based on a rainstorm with a 100-year return period following contemporary models (STEB 2011, personal communication), assuming a similar climate during the late Roman Medieval period. For current conditions, this storm event is estimated with $1.136 \times 10^{-5} \mathrm{~m} / \mathrm{s}$ of precipitation lasting 3,600 $\mathrm{s}$. As the whole study area was densely covered with buildings and sealed surfaces, we estimate a concentrated inflow of water on the 2D model by taking into account the flow of a 4-10 m wide section.
The Romans installed and maintained an elaborate dewatering system in CCAA. Fresh water was brought to the city by a $100 \mathrm{~km}$ long aqueduct from the Eifel Mountains. The constantly running water had to be systematically drained to the Rhine River. The two sewers bordering the study area in the north and the south were essential parts of the dewatering system. Already in the fourth century CE, due to lack of maintenance, accumulated sediments began to block the sewers and after the decline of the Roman Empire, the system ceased to function. Ingenious dewatering canals also existed underneath the Praetorium. It may be assumed that these were also no longer maintained after the Roman period, and the previous wellcontrolled water runoff of the study area ceased to function.

To simulate the effect of construction pits cutting through the loam layer, three voids of a width of $0.4 \mathrm{~m}$ were placed west of the edge of the slope (Fig. 17). Figure 18 summarizes results of a series of 15 tests with an increasing width of the water collection section showing seepage through three surfaces placed above and below the loam layer and at the top of the Quaternary material of the terrace (Fig. 17). Each seepage surface had a length of $6 \mathrm{~m}$. The seepage was monitored from the start of the rainfall to a total time of $8 \mathrm{~h}$, which is $7 \mathrm{~h}$ longer than the rain lasted. For raincollecting surface with a width of up to $5 \mathrm{~m}$, no significant amount of water penetrates the loam layer. However, a further increase in width of the collecting zone causes a significant water flow into the slope. The amount of water increases from 2.28 to $7.46 \mathrm{~m}^{3}$ for a rain-collecting surface of 5.25-10 $\mathrm{m}$ width, respectively.

For a width of this surface larger than $7 \mathrm{~m}$, a significant amount of water reaches even the Quaternary layer within $8 \mathrm{~h}$. The flow through the second measuring section below the loam layer is heavier than through the measuring section above, as a strong flow develops from west to east, down the slope on top of the loam. A part of this flow enters the voids without having crossed the top-measuring surface the same way water flows into a gully. For comparison, the seepage for the three measuring surfaces for a model without the voids is shown for the strongest inflow from a $10 \mathrm{~m}$ wide section. Without the voids, basically all water flows down the slope on top of the loam layer, resembling the situation before building construction began and dewatering became uncontrolled. The basic seepage model shows that for 
Fig. 17 Enlarged section of the $2 \mathrm{D}$ slope model used for seepage study. The blue arrows labeled Q1, Q2, and Q3 are the seepage control surfaces above and below the loam layer and in the top of the Quaternary terrace. Arrows above the surface indicate the boundary condition of a rainstorm. The location within the full model is indicated in Fig. 11

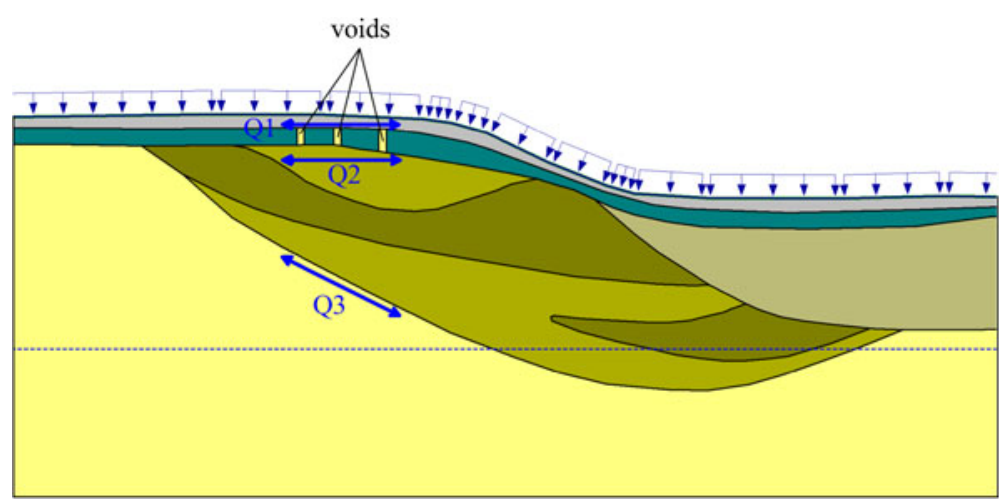

a heavy rainstorm, significant amounts of water can penetrate the voids in the loam layer and reach the groundwater level within a few hours.

\section{Discussion and conclusions}

The Lower Rhine Embayment is a young sedimentary basin with typical intraplate seismicity (Camelbeeck et al. 2007; Hinzen and Reamer 2007). The strongest

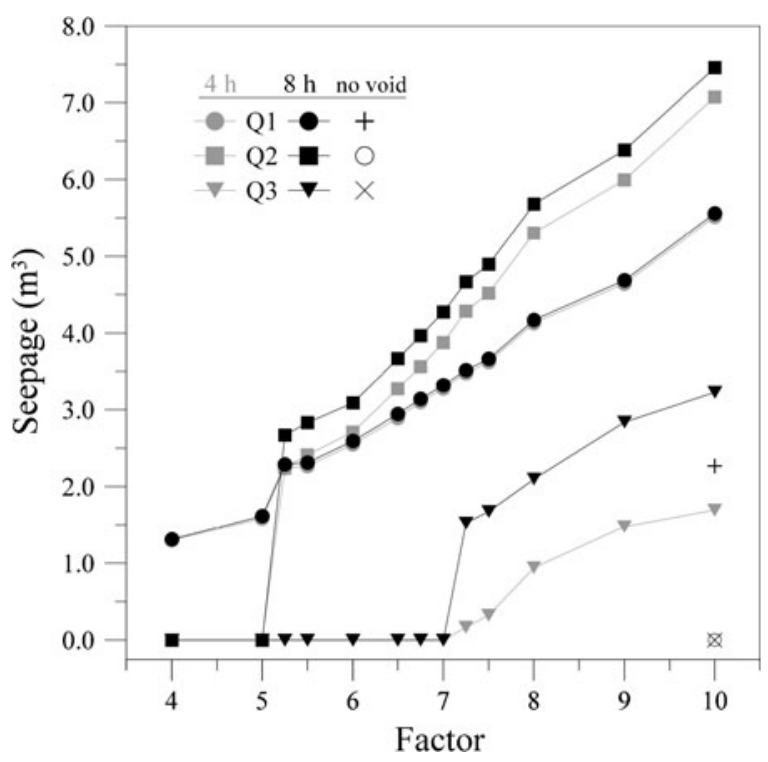

Fig. 18 Results of seepage modeling during a heavy rainfall with $1.136 \times 10^{-5} \mathrm{~m} / \mathrm{s}$ precipitation (100-year rainstorm for Cologne; STEB 2011, personal communication). The model takes into account an increasing width of a zone from which water reaches the top of the profile from 4 to $10 \mathrm{~m}$. Q1, Q2, and Q3 give the seepage volume crossing through three measuring surfaces within the model (Fig. 17). Gray and black symbols show the seepage after 4 and $8 \mathrm{~h}$ measured from the beginning of the 1-h rainfall duration, respectively. The crosses and open circle show the seepage for a model without voids in the loam layer instrumentally recorded earthquake in 1992 had a $\mathrm{M}_{\mathrm{W}}$ 5.4. Historical seismicity includes stronger events like the 1756 Düren earthquake $\left(M_{S} 5 \frac{3}{4}\right.$ (Camelbeeck et al. 2007)) and the 1692 Verviers earthquake $\left(\mathrm{M}_{\mathrm{S}} 61 / 4\right.$, (Camelbeeck et al. 2007)). In such a situation where larger earthquakes are rare, any information about former damaging earthquakes is of crucial importance for hazard evaluations. Several palaeoseismic studies in the area have shown that stronger earthquakes than those of the historic record occurred during Holocene times $\left(\mathrm{M}_{\mathrm{W}} \geq 6.3\right.$, Camelbeeck and Meghraoui 1998; Vanneste and Verbeeck 2001; Vanneste et al. 2001, 2008). The northern Rhine area has been occupied since Neolithic times and building activities began with the arrival of the Romans in the first century CE and lasted four centuries. This situation suggests that earthquakes have left their marks in the form of damage to buildings of the past two millennia. While Hinzen and Weiner (2009) showed that the hypothesis of a seismogenic cause of damages to a Neolithic water well was not plausible even though it was located in close proximity to one of the major active faults of the Lower Rhine Embayment, Hinzen (2005a) found strong arguments for earthquake damage to the Roman city fortifications of Tolbiacum, an important road junction west of Cologne. While time estimates for the damage contain large uncertainties, radiocarbon dating indicates the second half of the fourth century CE.

Possible earthquake damage has also been proposed for a rural Roman building (Hinzen 2005b), for the Carolingian Cathedral of Aachen (Reicherter et al. 2011), and Roman structures in the city center of Cologne (Hinzen and Schütte 2003). The latter include structures studied in detail in this contribution. While Doppelfeld (1956), Precht (1973), and Wolf (2000) argued for static settlements as the cause of this 
damage, Hinzen and Schütte (2003) argued for a more sudden event. Recent excavations (Schütte and Gechter 2011), new exploratory fieldwork, laboratory measurements, and the CVM of the excavation area offer a comprehensive database to document the cause of manifold damage.

The CVM compiled in this study facilitates a detailed analysis of all structural damage. The prevailing damage patterns are subsided and inclined foundation walls of Roman and Medieval origin. However, dating of the damage is in most cases affected by large uncertainties or a question of interpretation of the archeological contexts (Fig. 19). The new model of the natural subsurface, which is based on 350 single observations, provides a means for correlation of damage with the morphology of the study area. All major inclined structures including the eastern part of the massive Octagon of the Praetorium, the Roman wall in the Porticus, and the deformed and repaired Roman well, are located within the range of the slope of the Pleistocene Lower Terrace (Fig. 10). The major subsided structures, i.e., the entrance of the mikveh, the collapsed hypocaust, and the remains of deformed Medieval residential buildings, are located on top of the terrace. The isolated sand patches, which occur in the range of the slope as well as on top of the terrace must also be considered in the stability analysis. The distribution and structure of the damage pattern cannot be explained explicitly by seismically induced slope movements. An additional argument against earthquake-induced slope movement as a cause of damage is the slope stability indicated by our model calculations and the lack of typical shear fractures and corner expulsions in the walls. When utilizing geotechnical parameters from in situ and laboratory tests placed under the load of the largest assumed earthquakes, and including isolated sand layers in the slope model, the dynamic factor of slope safety stays well above equilibrium for the earthquake scenarios of activated local faults (Fig. 15).

Several structures were damaged later than the proposed time of the collapse of the Praetorium (Fig. 19). The heavily damaged cesspit of the Medieval synagogue was built in the first half of the tenth century $\mathrm{CE}$ and the damage likely occurred in the fourteenth century CE (Fig. 19). It is not clear when the walls in the entrance area of the mikveh were damaged; however, 14C dates indicate, that the basin of the mikveh was rebuilt around $1000 \mathrm{CE}$. Subsided walls of residential buildings in the Jewish quarter and a staircase from Late Medieval times (Fig. 19) are strong indicators for a recurrent instability of the subsurface as opposed to a single, sudden catastrophic event that damaged all structures in the study area.

The date of the damage of the Roman well located within the apse on the town hall square (Fig. 6) cannot be reliably determined. However, the well was repaired in the tenth century CE. Assuming that damage and repair were not separated by centuries, this result is a further argument for several damaging events.

A systematic summary of the results of an archeoseismological study becomes possible through a plausibility matrix, introduced by Hinzen (2005b) and Galadini et al. (2006). The matrix combines the observed and analyzed damages from a site with possible causes by stating whether the $i$ th cause is feasible, questionable, or unfeasible for a the $j$ th damage which is counted as $c_{i j}=+1,0$, and -1 for each cause/ damage combination, respectively. A plausibility in$\operatorname{dex} p_{j}$ is then calculated for each damage by:

$p_{j}=\frac{1}{2}+\frac{\sum_{i=1}^{n} c_{i j}}{2 \cdot n}$

which is a number between 0.0 and 1.0 .

Figure 20 shows the plausibility matrix for the major damage in the study area. A total of 11 different damaged sections of the study area are combined with six possible causes including: (1) slow static settlement, (2) natural deterioration, (3) flooding from the Rhine River, (4) anthropogenic action (war, water procurement from wells), (5) earthquake dynamic loading, and (6) subsurface erosion.

Effects of explosions from WWII bombs are found at several places in the excavation. In the northeastern Praetorium, a direct hit, marked in Fig. 4, destroyed a 5-m long section of a foundation wall. In total, some 150,000 bombs were dropped on Cologne during WWII. The last and largest bombing of Cologne was on March 2, 1945. The aerial surveillance photograph (Fig. 3) taken in April 1945 documents several bomb hits on the eastern section of the northern sewer. Taking into account that the bomb that damaged the 


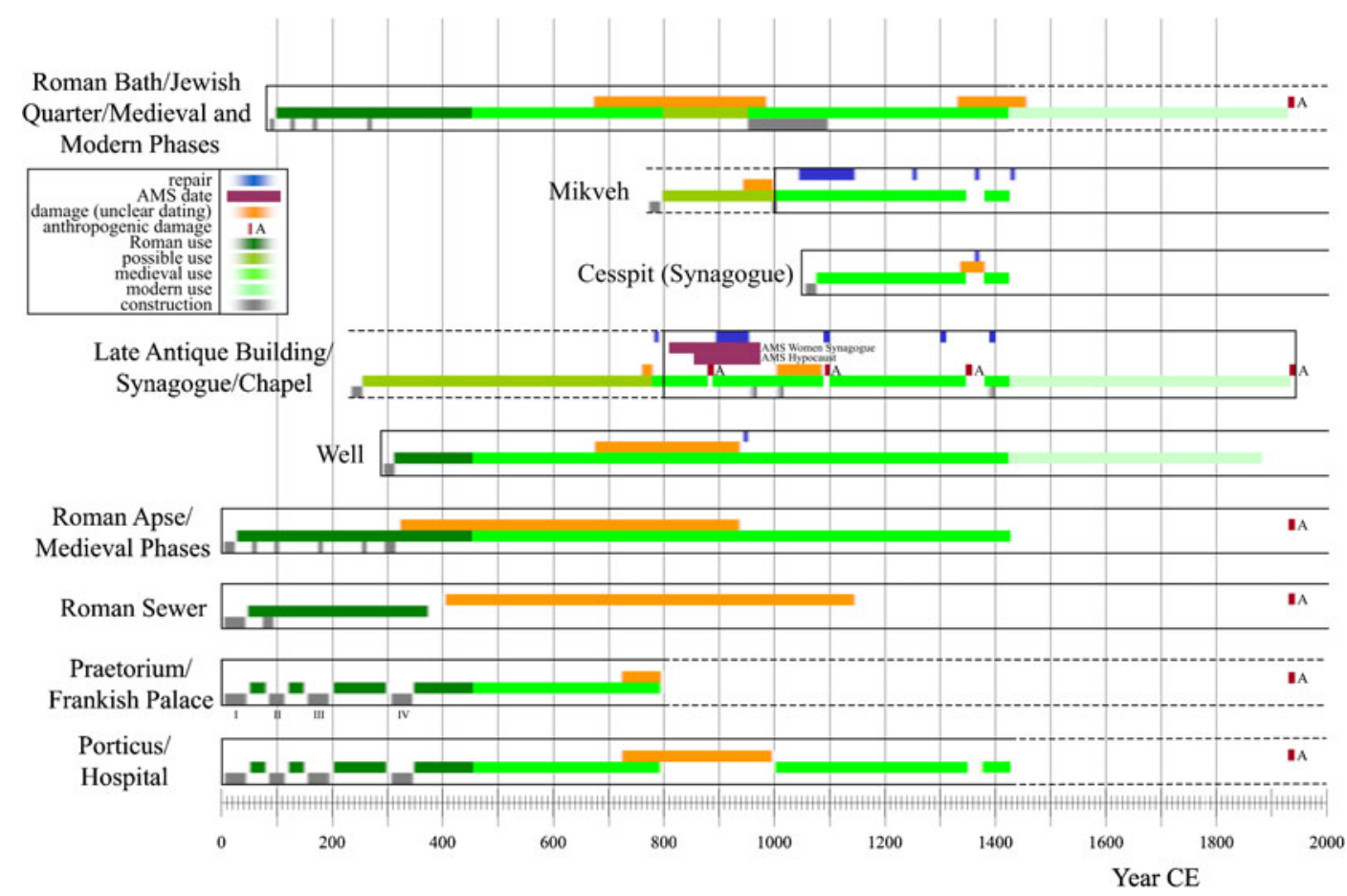

Fig. 19 Timeline for the Roman and Medieval constructions in the city center of Cologne. Eight sections of the study area are labeled on the left of the column diagrams. Gray sections indicate construction periods, green columns highlight the time periods during which the constructions were

Praetorium first penetrated the multistory city hall above it before reaching the underlying Roman foundations, it is feasible that the hit on the road above the sewer caused the structural damage in the sewer, in particular the crack in the concrete ceiling. Assuming a depth of the bomb crater of $2-3 \mathrm{~m}$, the explosion of a direct hit occurred only 4.5-2.5 $\mathrm{m}$ above the roof of the sewer. Sewer damage from bombing during WWII is also reported at other locations, i.e., in Newcastle upon Tyne and Sunderland (Ray 1996). in use; red-colored columns indicate possible times of damaging events and blue stands for reconstruction or repair times. Fading colors represent large uncertainty in the timing, and capital letters $A$ mark anthropogenic damages

Additional anthropogenic causes are the collateral extraction of fine-graded sand during the water procurement from numerous wells and additional loading to subsurface structures due to younger constructions. The first effect was deemed a feasible cause for the damage to the Roman well and the Late Medieval staircase and its surroundings. The bulging of sand into the Roman well in the apse after it had been excavated is a clear indication of a persisting mobility of wash dirt in the subsurface of the study area. The
Fig. 20 Plausibility matrix linking seven damage scenarios (rows) with 12 damage patterns in the study area in the city center of Cologne (see text for details)

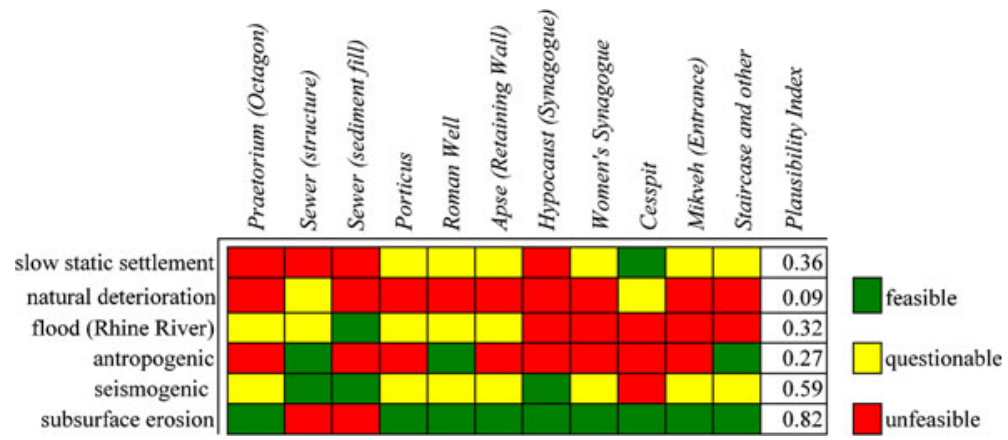


additional loading from artificial fill and constructions is counted as questionable for the structural damage of the sewer. This results in a plausibility index of $p=$ 0.27. Natural deterioration, or wear and tear, $(p=0.09)$ is unfeasible for all structures with the exception of the sewer and cesspit. For these two objects, it is counted questionable. Wear and tear could explain the spalling from the sidewalls of the sewer and the cesspit deformation. However, deterioration has not caused the sewer roof deformation. In these cases, wear and tear is rated questionable. While (repeated) flooding from the Rhine River is a feasible explanation for the mobilized sediments in the sewer, flooding is questionable or even infeasible for most of the other damage (Fig. 20) resulting in an index of $p=0.32$.

We assigned slow static settlements as a questionable but not completely impossible cause for six of the damage types and feasible for the cesspit. The reworked sediments that filled the sewer and the collapse of the hypocaust under the synagogue were not caused by slow static settlement. Due to the lack of any traces of repair attempts, we consider it also infeasible for the broken Octagon. The index for this damage cause is 0.36 .

A seismogenic cause is counted feasible for the structural damage of the sewer as well as the mobilization of its sediment fill and for the collapsed hypocaust. The deformed cesspit is most probably not a result of coseismic damage. For all other structures, the seismogenic cause is rated as questionable because they do not exhibit direct vibration damage but are a consequence of subsurface deformation. In addition, the results of the model calculations showed the stability of the slope and the improbability of liquefaction even during strong ground motions. The $p$ value for a seismogenic cause is 0.59 .

With the exception of WWII bombing, the most recent damage (cesspit and Jewish quarter) date to the fourteenth and fifteenth century CE. Covering a time span from the fourth to the end of the tenth century $\mathrm{CE}$, and in case of the sewer up to the twelfth century CE, the damage to the Roman structures (well, apse, sewer, Praetorium, Porticus) are not precisely dated (Fig. 19). The time of damage to the mikveh in the tenth century CE overlaps with most of the long time windows for the damage to Roman structures, however, not with the relative short window for the Praetorium at the end of the eighth century CE. This timeline argues for at least three separate damaging events in addition to the WWII destruction.
While written sources around $800 \mathrm{CE}$ are scarce due to the destruction wrought by the Norman invasions $(881 / 882)$, it is unlikely that strong damaging earthquakes later than 900 would be missing from the historic records. Ground motions capable of generating the heavy secondary damage in the study area require an earthquake that would have caused widespread damage in and around Cologne and outlying areas. Therefore, even if the occurrence of the earthquake was suppressed in Cologne for political reasons (a natural catastrophe would have likely been interpreted as a heavenly punishment), its effects would have been recorded elsewhere. This absence-ofwritten-evidence argument also applies to a multiple earthquake hypothesis, at least with respect to the more recent damage; however, comprehensive research in historic archives (i.e., Byzantine) would be worthwhile.

The subsurface erosion and/or internal and contact suffusion, especially of isolated sand lenses above the gravel sands of the Lower Terrace, are considered a feasible explanation for nine of the 11 damage areas (Fig. 20), resulting in $p=0.82$. The seepage models show that for a punctured flood loam layer, the hydraulic conductivity of the subsurface is high enough to quickly transport large amounts of water towards the sand layers during rainstorm events. Large parts of the study area were hydraulically sealed; this applies to the Praetorium itself but also to the current town hall square. During the imperial period, a sophisticated and well-maintained dewatering system existed in Cologne. In addition to rainwater accumulation, the water from the Eifel aqueduct with a maximum daily discharge of 21,000 $\mathrm{m}^{3}$ (Brinker 1986) required drainage towards the Rhine River front and ultimately into the river. Due to the fast progressing sedimentation of the northern sewer in the fourth century CE (Schütte and Gechter 2011), the sediments, which even included several dog skulls, are a clear indication of a lack of maintenance and a rapid decline of the dewatering system. Several water channels existed under the foundations of the Praetorium. A major drainage canal conducted rainwater from a collecting basin northwest of the Octagon, part of the CVM, towards the area in front of the Octagon, where it met with other canals in front of an outlet through the Praetorium front façade. If these and other drainage systems were no longer maintained after the Roman period, as with the northern sewer, uncontrolled seepage was the likely cause of damage. 
The massive foundations of the front wall of the Praetorium directly east of the Octagon reaching a depth of 42.7 masl (which is $3 \mathrm{~m}$ deeper than in the western part of the Octagon, (Precht 1973)) and consisting of opus caementicium show that the Roman engineers were aware of stability problems in this area. This interpretation is supported by several retaining walls from earlier periods within the terrace slope. The change in the foundation toward the north to a much more simple pile grading foundation has so far been interpreted as a consequence of two building phases. However, an additional reason could be the original topography and that the engineers adjusted the strength of the foundations to accommodate the geological conditions of the subsurface, for example, in form of sand lenses. The deformation analysis based on the CVM indicates a deficiency of $\sim 20 \mathrm{~m}^{3}$ in the subsurface east of the Octagon foundation. This is roughly equivalent to a $0.5 \mathrm{~m}$ thick sand layer stretching over an area of $5 \times 8 \mathrm{~m}$, and it is plausible that such an amount of material was washed out. Taking into account that the grain size of the analyzed sand lenses from the outcrops in the excavation are highly sensitive to subsurface transport (Prinz and Strauss 2006) and that given the climate conditions, heavy rainstorms, especially during summer season would not be unusual, repeated internal suffusion, contact suffusion, and finally erosion becomes a feasible cause for damage.

The collapsed hypocaust floor under the synagogue shows an inclination of $200 \mathrm{~mm} / \mathrm{m} \mathrm{(1:5)} \mathrm{at} \mathrm{its} \mathrm{base}$ where it is sitting on top of an isolated sand lens. Stateof-the-art engineering knowledge (i.e., Prinz and Strauss 2006) predicts substantial fractures in walls and structural damage at inclinations of 1:150 and total loss of buildings at 1:20, four times less than our observation. The convex bend of the subsurface (Fig. 7) introduced significant tensile forces in the concrete floor on top of the tile columns, leading to a collapse of the structure. This makes a subsidence due to sediment loss a feasible explanation of the hypocaust collapse.

The structural damage of the structure underneath the women's synagogue including the extrusion of a part of the massive foundation together with its $3.3^{\circ}$ inclination in the lower part is compatible with a washout of sediments in the subsurface in the northeastern corner of the women's synagogue. The women's synagogue is only $5 \mathrm{~m}$ from the Roman well that showed even recent sediment bulging during the excavation. Sharp-edged fractures cutting through blocks of the upper Medieval section are an indicator of a sudden event. From the archeological context, it is not yet clear whether the lower Roman and upper (possibly) Medieval sections were damaged at the same time. If the damage occurred concurrently a vibration-induced damage is not likely; vibrations strong enough to break and shift parts of the strong Roman foundation, would have severely damaged or even collapsed the rather fragile Medieval top construction (Fig. 8).

The damage rated as not feasibly produced by seepage (Fig. 20) occurs in the northern sewer. A possible explanation for the mobilized sediments is the repeated Rhine River flooding and the structural damage, especially the cracked roof of the eastern sewer section, is offered by the dynamic impact of WWII bombing.

Hinzen and Schütte (2003) estimated liquefaction potential in the uppermost $3 \mathrm{~m}$ of the Praetorium site with factors of safety of 1.02 based on a simple levelground liquefaction analysis. However, our updated subsurface model and the ground water table data indicate that such shallow sections stay dry even during high water levels of the Rhine River. The groundwater-saturated layers are more than $10 \mathrm{~m}$ below the surface, and due to the large overburden are unlikely to liquefy, an interpretation, which is also supported by our dynamic slope stability calculations.

Based on the data acquired in the frame of this study (including the comprehensive virtual model and the subsurface model) and the current status of the excavation, a seismogenic cause of all the damages is less probable than previously hypothesized. In particular, the results of the slope stability tests indicate a subsurface stable even under significant dynamic loading. Barring new data with a clear suggestion of earthquake damage from the planned excavations of the southern part of the Praetorium, we favor the interpretation of seepage effects and subsurface erosion as explanation for the settlement-induced building failures in more than one event and WWII bombing in case of the broken sewer roof. Subsurface mobility of sandy material is also discussed as a possible cause of the dramatic collapse of the historic Cologne city archive in 2009, which was located next to a subway construction site on the Lower Terrace of the Rhine River. 
Acknowledgments We are grateful to the whole team the Archaeological Zone Cologne for the support of the fieldwork especially to W. Münter. We thank M. Gechter, K. Kliemann, S. Schütte, and M. Wiehen for numerous discussions on all aspects of the excavation. S. Oesinghaus of Kühn Geoconsult significantly supported the determination of geotechnical parameters and R. Esser helped with the field and laboratory work. M. Wegner worked on the seismotectonic model and the synthetic groundmotions. G. Schweppe and H. Kehmeier helped during fieldwork, with the creation of some figures and text processing, respectively. The Kölner Verkehrsbetriebe provided information on exploratory boreholes for the subsurface model. The Stadtentwässerungsbetriebe Köln provided the data on Cologne precipitation. We thank S. Marco, T. Niemi, T. Tuttle, K. Vanneste, and $\mathrm{K}$. Verbeeck for their discussions on mobilized sediments. Comments from an anonymous reviewer were of great help and we appreciate the work by editorial manager D. Javinal and chief editor T. Dahm. This work was financed by Deutsche Forschungsgemeinschaft (DFG) grant HI 660/2-1.

Open Access This article is distributed under the terms of the Creative Commons Attribution License which permits any use, distribution, and reproduction in any medium, provided the original author(s) and the source are credited.

\section{References}

Ahorner L (1962) Untersuchungen zur quartären Bruchtektonik in der Niederrheinischen Bucht. Eiszeitalter und Gegenwart 13:24-105

Ahorner L (2001) Abschätzung der statistischen Wiederkehrperiode von starken Erdbeben im Gebiet von Köln auf Grund von geologisch-tektonischen Beobachtungen an aktiven Störungen. DGG-Mitt 02(2001):2-11

Alexandre P, Kusman D, Petermans T, Camelbeeck T (2008) The 18 September 1692 Earthquake in the Belgian Ardenne and its aftershocks. Hist Seismol 2:209-230. doi:10.1007/978-1-4020-8222-1_10

Ambraseys N (2005) Archaeoseismology and neocatastrophism. Seismol Res Lett 76:560-564

Brinker W (1986) Überlegungen zur Hydrologie und Hydraulik der Eifelleitung. In: Grewe K (ed) Atlas der römischen Wasserleitungen nach Köln. Rhein Ausgrabungen 26:235-247

Bronk Ramsey C (2009) Bayesian analysis of radiocarbon dates. Radiocarbon 51(1):337-360

Budny M (1984) Seismische Bestimmung der Bodendynamischen Kennwerte von oberflächennahen Schichten in Erdbebengebieten der Niederrheinischen Bucht und ihre ingenieurseismologische Anwendung. Sonderveröff Geol Inst Uni Köln 57:208

Camelbeeck T, Meghraoui M (1998) Geological and geophysical evidence for large palaeo-earthquakes with surface faulting in the Roer Graben (northwest Europe). Geophys J Int 132(2):347-362

Camelbeeck T, van Eck T, Pelzing R, Ahorner L, Loohuis J, Haak HW, Hoang-Trong P, Hollnack D (1994) The 1992 Roermond earthquake, the Netherlands, and its aftershocks. Geol Mijnb 73:181-197
Camelbeeck T, Vanneste K, Alexandre P, Verbeeck K, Petermans T, Rosset P, Everaerts M, Warnant R, VanCamp M (2007) Relevance of active faulting and seismicity studies to assessments of long-term earthquake activity and maximum magnitude in intraplate northwest Europe, between the Lower Rhine Embayment and the North Sea. In: Stein S, Mazzotti S (eds) Continental Intraplate Earthquakes; Secience, Hazard, and Political Issues. Geological Society of America Special Paper 425, pp 193-224

Crosta G, di Prisco C (1999) On slope instability induced by seepage erosion. Can Geotech J 36:1056-1073

Doppelfeld O (1953) Hafenfunde vom Altermarkt in Köln. Bonner Jahrb 153:102-125

Doppelfeld O (1956) Römische Großbauten unter dem Kölner Rathaus. Vorbericht über die Rathausgrabung des Jahres 1953. Germania 34:83-99

Dziewonski AM, Anderson DL (1981) Preliminary reference earth model. Phys Earth Planet Inter 25:297-356

Ellenblum R, Marco S, Agnon A, Rockwell T, Boas A (1998) Crusader castle torn apart by earthquake at dawn, 20 May 1202. Geology 26:303-306

Erdbaulaboratorium Essen (1998) Nord-Süd-Stadtbahn Köln-Baugrunduntersuchung 1998, by Kowalewski, Ehl

Erdbaulaboratorium Essen (2002) Nord-Süd-Stadtbahn KölnBaugrunduntersuchung 2002; by Ehl.

Erdbaulaboratorium Essen (2005). Nord-Süd-Stadtbahn KölnVerflechtungsstrecke Bechergasse-LV 2010-Ergänzende Baugrunduntersuchung während der Bauzeit durch Bohrungen, Rammsondierungen und Rammkernsondierungen, by Könermann, Hammacher, Estermann

Farifteh J, Soeters R (1999) Factors underlying piping in the Basilicata region, southern Italy. Geomorphology 26:239251

Fleischer C, Hinzen K-G, Schreiber S (2010) Laserscanning eines römischen Brunnens in der Archäologischen Zone Köln. Allg Vermessungs-Nachr 5(2010):176-180

Galadini F, Hinzen K-G, Stiros S (2006) Archaeoseismology: methodological issues and procedure. J Seismol 10:395414

Gechter M, Schütte S (2000) Ursprung und Voraussetzungen des mittelalterlichen Rathauses und seiner Umgebung. In: Geis W, Krings U, Stadt Köln (eds) StadtspurenDenkmäler in Köln. Köln: Das gotische Rathaus und seine historische Umgebung, Bd. 26. J.P. Bachem, Köln, pp 69 195

Gelenius A (1645) De admiranda, sacra, et civili magnitudine Coloniae Claudiae Agrippinensis Augustae Ubiorum Urbis. Kalcovius, Koeln

GFM Umwelttechnik (2008) Baugrundgutachten im Bereich des Historischen Rathauses in Köln, Alter Markt

Geologisches Landesamt NRW (1986) Ingenieurgeologische Karte 1:25000, Blatt 5007 Köln, GLA Krefeld

GeoStudio (2007) Version 7.15, Geo-Slope International Ltd. Calgary, Alberta, Canada

Guidoboni E (2002) Historical seismology: the long memory of the inhabited world. In: Lee WHK, Kanamori $\mathrm{H}$, Jennings $\mathrm{PC}$, Kisslinger $\mathrm{C}$ (eds) International handbook of earthquake $\&$ engineering seismology. International geophysics series 81A. Academic, Amsterdam, pp $775-790$ 
Hellenkemper H (1980) Der römische Rheinhafen und die ehemalige Rheininsel. Köln II Führer zu vor-und frühgeschichtlichen Denkmälern:126-134

Hinzen K-G (2005a) The use of engineering seismological models to interpret archaeoseismological findings in Tolbiacum, Germany: a case study. Bull Seismol Soc Am 95:521-539

Hinzen K-G (2005b) Archaeoseismological case study of a villa in Kerkrade Holzkuil, The Netherlands. In: Tichelman D, et al. (eds) Het villacomplex Kerkrade-Holzkuil, ADCrapport 155. Amersfoort, pp 407-420

Hinzen K-G (2011) Archäoseismologie-Auf der Suche nach Spuren vorinstrumenteller Erdbeben. Akademie der Wissenschaften und Künste Nordrhein-Westfalen. Ferdinand Schöningh, Paderborn

Hinzen K-G, Reamer SK (2007) Seismicity, seismotectonics, and seismic hazard in the Northern Rhine Area. Geol Soc Am, Spec Pap 425:225-242

Hinzen K-G, Schütte S (2003) Evidence for earthquake damage on roman buildings in cologne, Germany. Seismol Res Lett $74: 124-140$

Hinzen K-G, Weiner J (2009) Testing a seismic scenario for the damage of the Neolithic wooden well of Erkelenz-Kueckhoven, Germany. Geol Soc, Lond, Spec Pub 316:189-205. doi:doi:10.1144/SP316.12

Hinzen K-G, Schreiber S, Yerli B (2010) The Lycian Sarcophagus of Arttumpara, Pinara, Turkey: testing seismogenic and anthropogenic damage scenarios. Bull Seismol Soc Am 100(6):3148-3164

Höhlbaum K (1887) Das Buch Weinsberg. Kölner Denkwürdigkeiten aus dem 16 Jahrhundert II

Holthausen D (1994) Reliefentwicklung und Bodenkontamination der Kölner Altstadt seit der Römerzeit. Institute of Geography, Cologne University, Cologne, Diploma Thesis, $136 \mathrm{p}$

Institut für Geotechnik Offer (2000) Generalisierung Rathaus Spanischer Bau-Überdachung des Innenhofs-Gutachten

Jones JAA (2004) Implications of natural soil piping for basin management in Upland Britain. Land Degradation Dev 15:325-349

Köhler H (1941) Die stadt Köln. Natürliche Grundlagen des Werdens einer Großstadt. Inaugural Dissertation Universität zu Köln, Zur Wirtschaftsgeographie des deutschen Westens 7. Volk-und-Reich, Berlin

Kramer SL (1996) Geotechnical earthquake engineering. Prentice Hall, New Jersey

La Baume P (1980) Das römische Köln: Geschichtlicher Überblick. Köln I Führer zu vor- und frühgeschichtlichen Denkmälern:38-52

Lückger H-J (1919) Studien über das Rheingelände des Roemischen Coeln. Bonner Jahrbücher. Sonderdruck 125:163-182

Marco S (2008) Recognition of earthquake-related damage in archaeological sites: examples from the Dead Sea fault zone. Tectonophysics 453:148-156

Martel SJ (2011) Mechanics of curved surfaces, with application to surface-parallel cracks. Geophys Res Lett 38(20): L20303. doi:10.1029/2011gl049354

Meghraoui M, Gomez F, Sbeinati R, Van der Woerd J, Mouty M, Darkal AN, Radwan Y, Layyous I, Al Najjar H, Darawcheh R, Hijazi F, Al-Ghazzi R, Barazangi M (2003) Evidence for 830 years of seismic quiescence from palaeoseismology, archaeoseismology and historical seismicity along the Dead Sea fault in Syria. Earth Planet Sci Lett 210(1-2):35-52. doi:10.1016/s0012-821x(03)00144-4

Nikonov AA (1988) On the methodology of archaeoseimic research into historical monuments. In: Marinos PG, Koukis GC (eds) The engineering geology of ancient works, monuments and historical sites, preservation and protection, Proc. of an Int. Symp. organized by the Greek National Group of IAEG, Athens Sept. 19-23 1988. Rotterdam, The Netherlands, pp 1315-1320

Precht G (1973) Baugeschichtliche Untersuchung zum römischen Praetorium in Köln. Rhein Ausgrabungen 14:120

Prinz H, Strauss R (2006) Abriss der Ingenieurgeologie. Spektrum Akademischer, Heidelberg

Ray J (1996) The night blitz: 1940-1941. Cassell Military, London, p 288

Reamer SK, Hinzen K-G (2004) An Earthquake Catalog for the Northern Rhine Area, Central Europe (1975-2002). Seismol Res Lett 75(6):713-725

Reicherter K, Schaub A, Fernndez-Steeger TM, KohlbergerSchaub T, Grützner C (2011) Historische Erdbebenschäden im Dom zu Aachen: aquisgrani terrae motus factus est. Schrift Karlsvereins 13-2011:109-128

Reimer PJ, Baillie MGL, Bard E, Bayliss A, Beck JW, Blackwell PG, Bronk Ramsey C, Buch CE, Burr GS, Edwards RL, Friederich M, Grootes PM, Guilderson TP, Hajdas I, Heaton TJ, Hogg AG, Hughen KA, Kaiser KF BK, McCormac FG, Manning SW, Reimer RW, Richards DA, Southon JR, Talamo S, Turney CSM, van der Pflicht J, Weyenmeyer CE (2009) IntCal09 and Marine09 radiocarbon age calibration curves, 0-50,000 years cal BP. Radiocarbon 51 (4):1111-1150

Schmedes J, Hainzl S, Reamer SK, Scherbaum F, Hinzen K-G (2005) Moment release in the Lower Rhine Embayment, Germany: seismological perspective of the deformation process. Geophys J Int 160:901-909

Schreiber S, Hinzen KG (2011) Damage assessment in archaeoseismology: methods and application to the archaeological zone Cologne, Germany. In: Grützner C, Pérez-Lopez R, Fernández Steeger $\mathrm{T}$ et al. (eds) Earthquake Geology and Archaeology: Science, Society and Critical facilities. Proceedings of the 2nd INQUA-IGCP 567 International Workshop on Active Tectonics, Earthquake Geology, Archaeology and Engineering, Corinth, Greece, 2011. pp 222-225

Schreiber S, Hinzen KG, Fleischer C (2009) An application of 3D laser scanning in archaeology and archaeoseismology: The Medieval cesspit in the archaeological zone Cologne, Germany. In: 1st INQUA-IGCP-567 International Workshop on Earthquake Archaeology and Palaeoseismology, Baelo Claudia, Cadiz, Spain, 7-13 September 2009. pp 136-138

Schreiber S, Hinzen KG, Fleischer C, Schütte S (2012) Excavation parallel laser scanning of a Medieval cesspit in the archaeological zone cologne, Germany. Journal of Computing and Cultural Heritage (in press)

Schultze R, Steuernagel C, Nissen H (1885) Colonia Agrippinensis. Ein Beitrag zur Ortskunde der Stadt Köln zur Römerzeit. Bonner Jahrb 98:144

Schütte S, Gechter M (2011) Köln Archäologische Zone / Jüdisches Museum. Von der Ausgrabung zum Museum. 
Kölner Arächologie zwischen Rathaus und Praetorium, Ergebnisse und Materialien 2006-2011 Stadt Köln, Köln

Seed, H.B. und Idriss, I.M. (1970) Soil moduli and damping factors for dynamic response analysis. Report EERC 7010, Earthquake Engineering Research Center, University of California, Berkeley, $37 \mathrm{p}$

Seismological Station Bensberg (2009) Results of auger cores in the AZC. Internal Report. Erdbebenstation Bensberg

Stadtentwässerungsbetriebe Koeln, STEB (2009) Wasserstände in Köln. URL: http://www.steb-koeln.de/hochwasser.html. Accessed: 02 Dec 2009

Stück H, Forgó LZ, Rüdrich J, Siegesmund S, Toeroek Á (2008) The behaviour of consolidated volcanic tuffs: weathering mechanisms under simulated laboratory conditions. Environ Geol 56:699-713

Tillsmanns \& Partner GmbH (2009) Geotechnische Untersuchungen im Bereich des Historischen Rathauses in Köln, Alter Markt, zur Beurteilung des Baugrundes im Zusammenhang mit dem Bau der U-Bahn, by Wagner, Fischer

Vanneste K, Verbeeck K (2001) Detailed Palaeoseismic investigation of the Rurrand Fault in Hambach Trench, Germany. Cah Cent Eur Géodynamique et de Séismologie 18:153-156
Vanneste K, Verbeeck K, Camelbeeck T, Paulissen E, Meghraoui M, Renardy F, Jongmans D, Frechen M (2001) Surface rupturing history of the Bree fault scarp, Roer Valley graben; results from four years of palaeoseismological investigation. Cah Cent Eur Géodynamique et de Séismologie 18:147-152

Vanneste K, Mees F, Verbeeck K (2008) Thin section analysis as a tool to aid identification of palaeoearthquakes on the slow, active geleen fault, roer valley graben. Tectonophysics 453:94-109

Vanneste K, Camelbeeck T, Verbeeck K (2012) A model of composite seismic sources for the Lower Rhine Graben, NW Europe. Bull Seismol Soc Am (submitted)

Vucetic M, Dobry M (1991) Effect on soil plasticity on cyclic response. J Geotech Eng ASCE 117:89-107

Wang R (1999) A simple orthonormalization method for stable and efficient computation of Green's functions. Bull Seismol Soc Am 89:733-741

Weber B, Hinzen K-G (2006) Bodenverstärkungen in der südlichen Niederrheinischen Bucht. Bauingenieur 81:9-15

Wolff G (2000) Das Roemisch-Germanische Köln-Führer zu Museum und Stadt. Bachem, Köln 